\title{
ADRIANA DE CÁSSIA ORTIZ
}

Influência do diabetes mellitus sobre a expressão gênica em larga escala de célulastronco mesenquimais derivadas da medula óssea

Tese apresentada à Faculdade de Odontologia de Ribeirão Preto para obtenção do título de Doutor em Ciências pelo Programa de Pós-Graduação em Biologia Oral

Orientador: Prof. Dr. Adalberto Luiz Rosa

\section{Ribeirão Preto}


Autorizo a reprodução e divulgação total ou parcial deste trabalho, por qualquer meio convencional ou eletrônico, para fins de estudo e pesquisa, desde que citada a fonte.

Ficha Catalográfica

Biblioteca Central USP Ribeirão Preto

Faculdade de Odontologia de Ribeirão Preto da Universidade de São Paulo

Ortiz, Adriana de Cássia

Influência do diabetes mellitus sobre a expressão gênica em larga escala de células-tronco mesenquimais derivadas da medula óssea. Ribeirão Preto, 2018.

45 p. : il. ; $30 \mathrm{~cm}$

Tese de Doutorado, apresentada à Faculdade de Odontologia de Ribeirão Preto/USP.

Área de concentração: Biologia Oral.

Orientador: Rosa, Adalbeto Luiz.

1. Diabetes mellitus. 2. Células-tronco. 3. Osteoblastos. 4 Osteogênese. 5. Expressão gênica. 


\section{FOLHA DE APROVAÇÃO}

Nome: Adriana de Cássia Ortiz

Título: Influência do diabetes mellitus sobre a expressão gênica em larga escala de célulastronco mesenquimais derivadas da medula óssea

Tese apresentada à Faculdade de Odontologia de Ribeirão Preto da Universidade de São Paulo para obtenção do título de Doutor em Ciências pelo Programa de Pós-Graduação em Biologia Oral

Aprovado em:

BANCA EXAMINADORA

Prof. Dr.

Instituição: Assinatura:

Prof. Dr.

Instituição: Assinatura:

Prof. Dr. Instituição: Assinatura:

Prof. Dr.

Instituição: Assinatura: 



\section{AGRADECIMENTOS}

Á Deus e a minha família por estarem comigo nesta jornada.

Ao magnífico Reitor da Universidade de São Paulo, Prof. Dr. Vahan Agopyan.

À Faculdade de Odontologia de Ribeirão Preto, representada pela Diretora Profa. Dra. Léa Assed Bezerra da Silva.

Ao Programa de Pós Graduação em Biologia Oral, coordenado pelo Prof. Dr. Márcio Mateus Beloti.

Ao meu orientador, Prof. Dr. Adalberto Luiz Rosa, pelos ensinamentos e por ter me concedido a realização deste projeto, que muito contribuiu para o meu aperfeiçoamento profissional.

Ao Prof. Dr. Geraldo A. Passos e equipe, pela colaboração neste projeto e pela disponibilização do Laboratório de Imunogenética Molecular da Faculdade de Medicina para a execução das etapas experimentais deste trabalho.

Aos Profs. Pedro Sousa Gomes e Maria Helena Fernandes da Faculdade de Medicina Dentária da Universidade do Porto, pela participação neste estudo.

A todos os professores, funcionários, técnicos de laboratório e alunos pelos ensinamentos, contribuições e pela convivência.

À Capes, pelo suporte financeiro.

O presente trabalho foi realizado com apoio da Coordenação de Aperfeiçoamento de Pessoal de Nível Superior - Brasil (CAPES) - Código de Financiamento 001. 



\section{RESUMO}

ORTIZ, A. de C. Influência do diabetes mellitus sobre a expressão gênica em larga escala de células-tronco mesenquimais derivadas da medula óssea. 2018. 45 f. Tese (Doutorado) - Faculdade de Odontologia, Universidade de São Paulo, Ribeirão Preto, 2018.

O diabetes mellitus é uma doença crônica e de incidência crescente na população mundial. As desordens metabólicas decorrentes do diabetes podem causar sérias complicações em diversos órgãos. No tecido ósseo, o diabetes causa disfunção nas células, redução da formação óssea e alterações na microarquitetura do tecido, tornando-o mais suscetível a fraturas. Apesar de existirem muitas evidências acerca do efeito do diabetes sobre o metabolismo ósseo, as alterações induzidas pela doença sobre o genoma das células osteoprogenitoras têm sido pouco exploradas. Assim sendo, este estudo teve por objetivo comparar os perfis de expressão gênica em larga escala de células-tronco mesenquimais (CTMs) isoladas da medula óssea de ratos diabéticos e saudáveis. Para indução do diabetes, ratos machos Wistar (250 g) receberam uma única injeção intraperitoneal de estreptozotocina (STZ) diluída em tampão citrato (60 $\mathrm{mg} / \mathrm{Kg}$ ). O grupo controle recebeu uma única injeção de tampão citrato (veículo). O diabetes foi confirmado pela dosagem dos níveis de glicose sanguínea utilizando o Accu-Chek Active ${ }^{\circledR}$ (diabéticos $\geq 300 \mathrm{mg} / \mathrm{dL}$; controle $\leq 135 \mathrm{mg} / \mathrm{dL}$ ). Após 9 semanas da injeção, as CTMs foram coletadas dos fêmures dos ratos e cultivadas em meio de crescimento. Atingida a subconfluência, o RNA total foi extraído das células e a análise genômica foi realizada por microarray utilizando lâminas Agilent 4x44k. Os perfis de expressão gênica foram analisados pelo software GeneSpring 14.9 GX (Agilent), considerando um fold-change $\geq 2,0$ ( $\mathrm{p} \leq 0,05)$. A caracterização funcional dos genes diferencialmente expressos foi realizada pela database DAVID $(\mathrm{p} \leq 0,05)$ e os dados do microarray foram confirmados por PCR em tempo real. As CTMs isoladas dos ratos diabéticos apresentaram, em relação às CTMs dos ratos saudáveis, 848 genes induzidos e 1112 genes reprimidos. Os processos de diferenciação osteoblástica, regulação positiva da mineralização, inibição da atividade osteoclástica e processo regenerativo foram enriquecidos predominantemente por genes reprimidos, o que sugere que o diabetes pode ter um efeito inibitório sobre a osteogênese e a mineralização da matriz óssea. Adicionalmente, o diabetes induziu a expressão do gene Pparg, que é considerado um regulador chave da diferenciação adipogênica. Os resultados do microarray mostraram que o diabetes mellitus alterou as características moleculares das CTMs, influenciando a expressão 

de genes envolvidos com processos biológicos considerados relevantes para a formação e regeneração óssea.

Palavras-chave: Diabetes mellitus. Células-tronco. Osteoblastos. Osteogênese. Expressão gênica. 



\section{ABSTRACT \\ ORTIZ, A. de C. Influence of diabetes mellitus on large-scale gene expression of bone}

marrow mesenchymal stem cells. 2018. 45 f. Tese (Doutorado) - Faculdade de Odontologia, Universidade de São Paulo, Ribeirão Preto, 2018.

Diabetes mellitus is a chronic disease of increasing incidence in the world population. Metabolic disorders associated to diabetes can lead to serious complications in several organs. In bone tissue, diabetes causes cell dysfunction, reduced bone formation and changes in tissue microstructure, making it more susceptible to fractures. Although there is much evidence about the effect of diabetes on bone metabolism, the changes induced by this disease in the genome of osteoprogenitor cells have been poorly explored. Thus, this study aimed to compare the large-scale gene expression profiles of mesenchymal stem cells (MSCs) isolated from the bone marrow of healthy and diabetic rats. For diabetes induction, male Wistar rats $(250 \mathrm{~g})$ received a single intraperitoneal injection of streptozotocin (STZ) diluted in citrate buffer $(60 \mathrm{mg} / \mathrm{kg})$. The control group received a single injection of citrate buffer (vehicle). Diabetes was confirmed by the measurement of blood glucose levels using Accu-Chek Active $^{\circledR}$ (diabetic $\geq 300 \mathrm{mg} / \mathrm{dL}$, control $\leq 135 \mathrm{mg} / \mathrm{dL}$ ). After 9 weeks of injection, the MSCs were collected from the femurs and cultured in growth medium. Reaching the subconfluence, total RNA was extracted and genomic analysis was performed by microarray using Agilent $4 \mathrm{x} 44 \mathrm{k}$ slides. The gene expression profiles were analyzed by the GeneSpring $14.9 \mathrm{GX}$ software (Agilent), considering a fold-change $\geq 2.0(\mathrm{p} \leq 0.05)$. The functional characterization of the differentially expressed genes was performed by DAVID database $(p \leq 0.05)$ and the microarray data were confirmed by real-time PCR. MSCs isolated from diabetic rats showed, in relation to the MSCs of healthy rats, 848 induced genes and 1122 repressed genes. The osteoblastic differentiation, positive regulation of mineralization, inhibition of osteoclastic activity and regenerative process were enriched predominantly by repressed genes, suggesting that diabetes may have an inhibitory effect on osteogenesis and bone matrix mineralization. In addition, diabetes induced expression of the Pparg gene, which is considered a key regulator of adipogenic differentiation. The results of the microarray showed that diabetes mellitus altered the molecular characteristics of MSCs, influencing the expression of genes involved with biological processes considered relevant for bone formation and regeneration.

Keywords: Diabetes mellitus. Stem cells. Osteoblasts. Osteogenesis. Gene expression. 



\section{SUMÁRIO}

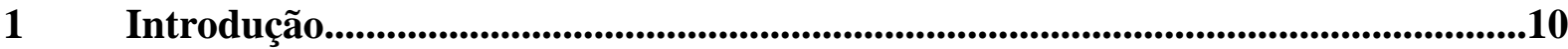

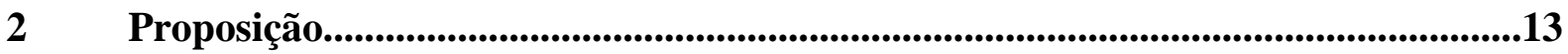

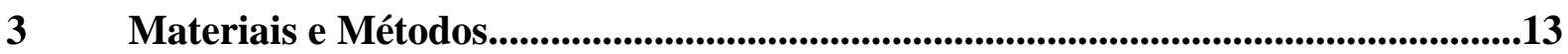

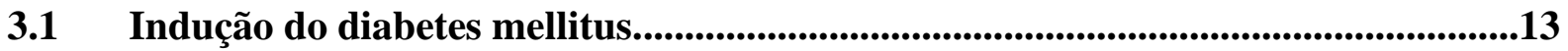

3.2 Obtenção e cultura de CTMs derivadas da medula óssea..........................................14

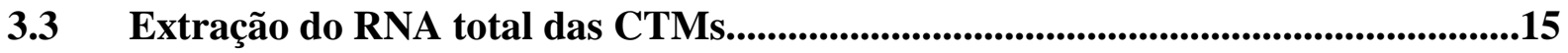

3.4 Quantificação e avaliação da integridade do RNA total..........................................15

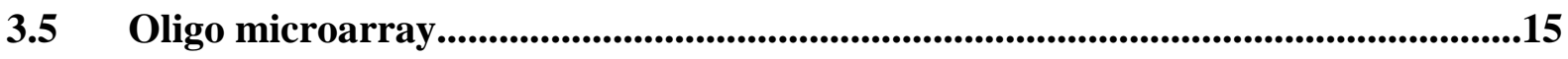

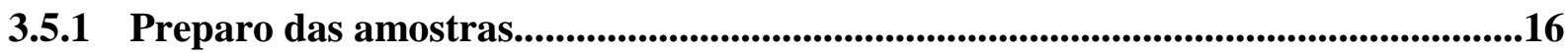

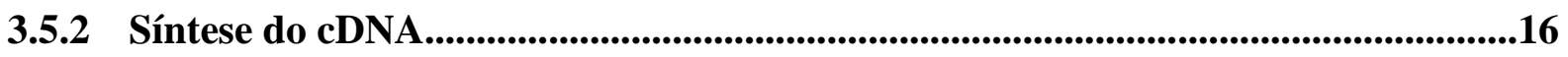

3.5.3 Síntese, amplificação e marcação do cRNA.......................................................17

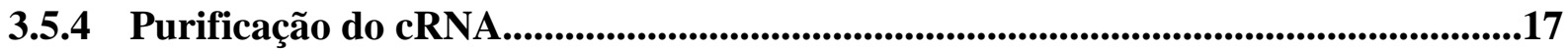

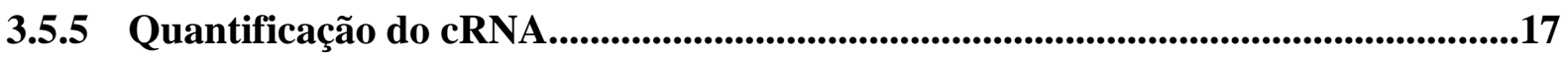

3.5.6 Hibridização.....................................................................................................................17

3.5.7 Lavagem das lâminas de microarray.....................................................................18

3.5.8 Escaneamento e extração dos dados.......................................................................18

3.5.9 Análise dos dados do microarray ...................................................................................18

3.5.10 Confirmação dos dados por PCR em tempo real....................................................19

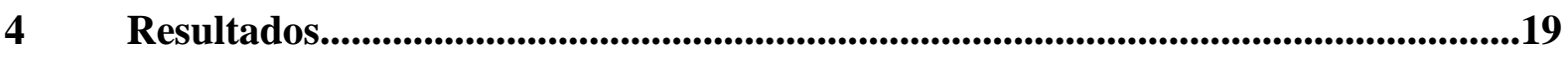

4.1 Dosagem dos níveis de glicose sanguínea...................................................................19

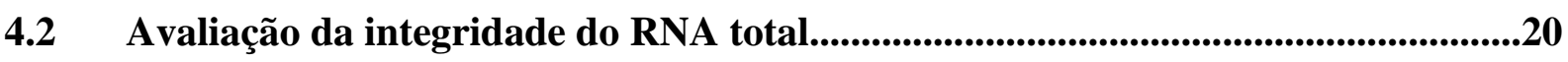

4.3 Análises dos mRNAs diferencialmente expressos...............................................22

4.4 Confirmação dos dados do microarray por PCR em tempo real...........................32 



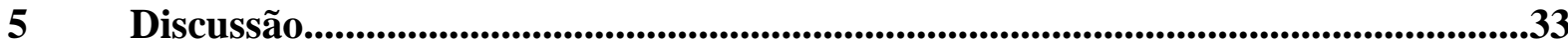

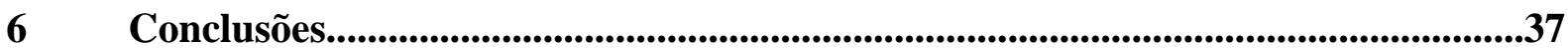

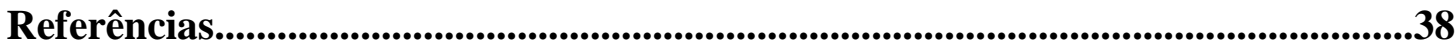

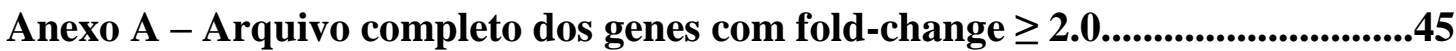





\section{Introdução}

O diabetes mellitus é uma doença crônica caracterizada por alterações nos níveis de glicose sanguínea e no metabolismo de carboidratos, gorduras e proteínas (Monseley, 2012; Yan \& Li, 2013). Essas desordens metabólicas podem acarretar sérias complicações com conseqüente comprometimento da qualidade de vida das pessoas portadoras da doença. O diabetes apresenta uma incidência crescente e atinge milhões de pessoas em todo o mundo. Segundo estimativas do IDF, International Diabetes Federation, o número de pessoas diabéticas era de 425 milhões em 2017 com expectativa de alcançar 629 milhões em 2045, o que se traduz em um aumento de $48 \%$ na incidência da doença na população mundial. Etiologicamente, o diabetes mellitus pode ser classificado em tipo I, que abrange aproximadamente $10 \%$ do total dos casos da doença, e tipo II, que compreende cerca de $90 \%$ dos casos. O diabetes mellitus tipo I apresenta uma etiologia auto-imune e acomete principalmente crianças e adolescentes. Nesse caso, o diabetes é causado pela produção deficiente de insulina decorrente da destruição das células pancreáticas tipo $\beta$. O diabetes mellitus tipo II é mais freqüente entre adultos e ocorre devido à resistência das células à ação da insulina associada à produção insuficiente desse hormônio pelo pâncreas. Características genéticas, envelhecimento, obesidade e sedentarismo são fatores predisponentes para a incidência do tipo II da doença (IDF Diabetes Atlas, 2017).

Em ambos os tipos de diabetes, a produção deficiente ou a resistência das células à insulina resultam no aumento dos níveis de glicose sanguínea. Ao longo do tempo, a hiperglicemia pode causar danos e disfunção em diversos tecidos e órgãos, como retina, rins, coração, sistema vascular, sistema nervoso e tecido ósseo (Jiao et al., 2015). A hiperglicemia contribui para as complicações do diabetes por induzir o estresse oxidativo das células e por aumentar a produção de espécies reativas de oxigênio, que são moléculas instáveis que podem modificar outras moléculas com as quais reagem (Baynes, 1991; Mangialardi et al., 2014). A hiperglicemia também atua aumentando significativamente a formação de produtos finais de glicosilação avançada e a produção de citocinas inflamatórias (Graves \& Kayal, 2008; Cruz et al., 2013; Jiao et al., 2015). Os produtos finais de glicosilação avançada ou AGEs (Advanced Glycation End Products) são formados pela ligação não-enzimática entre carboidratos e proteínas ou entre carboidratos e lipídeos, resultando em compostos altamente resistentes à digestão proteolítica que se depositam no plasma e nos tecidos, incluindo o tecido ósseo. 
No tecido ósseo, a hiperglicemia e seus produtos causam disfunção nos osteoblastos e osteócitos ( $\mathrm{Li}$ et al., 2015; Liu \& Jiang, 2017), células que, respectivamente, são responsáveis pela formação e manutenção da vitalidade do tecido. Os AGEs se ligam a receptores específicos RAGE (Receptor for Advanced Glycation End Products) presentes nos osteoblastos e osteócitos, alterando o metabolismo celular. Como consequência, ocorre o aumento da apoptose (Okazaki et al., 2012; Tanaka et al., 2015; Kanazawa, 2017; Palermo et al., 2017) e redução da capacidade proliferativa dessas células (Li et al., 2015), inibição da diferenciação osteoblástica (Ogawa et al., 2007; Garcia-Hernandez et al., 2012, Okazaki et al., 2012; Wu et al., 2012), da expressão de marcadores osteoblásticos e da mineralização óssea (Manavalan et al., 2012; Ehnert et al., 2015; Li et al., 2015; Liu \& Jiang, 2017; Wang et al., 2010). O efeito do diabetes sobre os osteócitos induz a expressão de esclerostina que, por ser um antagonista da via de sinalização Wnt/ $\beta$ catenina, atua inibindo a diferenciação osteoblástica e a formação óssea (Gaudio et al., 2012; Gennari et al., 2012; Meier et al., 2016; Delgado-Calle et al., 2017). Outro fator relevante a ser considerado diz respeito ao acúmulo de AGEs na matriz óssea, que altera a qualidade do tecido (Saito \& Marumo, 2013; Palermo et al., 2017) e compromete o processo de remodelação óssea (Vashishth et al., 2001; Saito et al., 2006; Meier et al., 2016). Além disso, a interação AGE-RAGE estimula a síntese de citocinas inflamatórias (Vlassara \& Striker, 2013; Liu \& Jiang, 2017), o que contribui com o aumento da apoptose celular, exacerba o processo inflamatório e prejudica o processo de regeneração tecidual (Jiao et al., 2015).

Além de alterar o metabolismo das células ósseas especializadas, a hiperglicemia também causa disfunção nas células-tronco mesenquimais (CTMs), uma população de células indiferenciadas presentes na medula óssea e em diversos outros tecidos. As CTMs são células que apresentarem alto potencial de proliferação e de diferenciação em diversas linhagens de células especializadas, como osteoblastos, condroblastos, adipócitos e mioblastos. (Owen et al., 1988; Prockop, 1997; Pittenger et al., 1999). Devido às características biológicas que apresentam, as CTMs têm uma participação relevante no processo de regeneração tecidual. As CTMs apresentam propriedades imunomodulatórias e imunossupressoras (Krampera et al., 2013; Montespan et al., 2014; Oryan et al., 2016), atividade angiogênica (Kachgal et al., 2011; Smadja et al., 2012; Manieri et al., 2015), efeito anti-apoptótico (Togel et al., 2007) e são capazes de migrar para sítios de lesão e de recrutar outras células osteoprogenitoras (Taguchi et al., 2005). As CTMs presentes na medula óssea apresentam considerável potencial de diferenciação osteoblástica e participam ativamente do processo de formação 
óssea (Sakaguchi et al., 2005; Peng et al., 2008; Niemeyer et al., 2010; Wu et al., 2015; Abuna et al., 2016, Brennan et al., 2017; Freitas et al., 2017).

A influência do diabetes sobre o metabolismo das CTMs e a repercussão desse efeito sobre o tecido ósseo têm sido muito investigado. Diversos estudos relatam que a hiperglicemia prejudica a mobilização celular (Fadini et al., 2013; Yu et al., 2015; Vasam et al., 2016), inibe a proliferação (Filion et al., 2017; Jin et al., 2010; Kim et al., 2013, Ko et al., 2015), o potencial de diferenciação osteoblástica (Lu et al., 2003; Filion et al., 2017; Juncheng et al., 2013; Zhao et al., 2013; Peng et al., 2016) e a atividade angiogênica (Kim et al., 2013; Schumann et al., 2015; Peng et al., 2016; Rezabakhsh et al., 2017) das CTMs. Lu e colaboradores (2003) investigaram o efeito do diabetes sobre a diferenciação osteoblástica das CTMs. Os resultados desse estudo mostraram que CTMs derivadas da medula óssea de camundongos diabéticos apresentaram uma expressão reduzida de osteocalcina $(O c)$ e dos fatores de transcrição runt-related transcription factor 2 (Runx2) e distal-less homeobox 5 (Dlx5), os quais estão diretamente envolvidos com a diferenciação osteoblástica. Jin e colaboradores (2010) avaliaram o potencial proliferativo de CTMs isoladas da medula óssea de ratos diabéticos e verificaram que a hiperglicemia limitou a capacidade proliferativa e o efeito anti-apoptótico das CTMs, in vitro, além de reduzir a produção de fatores de crescimento, como o fator de crescimento endotelial vascular (Vegf) e o fator de crescimento semelhante à insulina-1 (Igf-1). Stolzing e colaboradores (2010) verificaram que culturas de CTMs da medula óssea de ratos diabéticos apresentaram capacidade proliferativa reduzida, aumento de aproximadamente $90 \%$ nos níveis de AGE e RAGE, aumento de 33\% nos níveis de espécies reativas de oxigênio e alta taxa de apoptose celular, quando comparadas com as culturas de células saudáveis. Corroborando com esses achados, Weinberg e colaboradores (2014) obtiveram uma redução de aproximadamente $35 \%$ na população de CTMs da medula óssea de ratos diabéticos em relação aos ratos saudáveis quando cultivadas in vitro. Esses autores observaram uma redução de 20 a 25\% na atividade da fostatase alcalina, aos 10 dias de cultivo, e uma redução de cerca de $40 \%$ na formação de nódulos mineralizados, aos 21 dias de cultivo.

As desordens moleculares decorrentes do diabetes comprometem a formação óssea e alteram a microarquitetura do tecido (Santana et al., 2003; Hamann et al., 2011; García-Hernández et al., 2012; Tolosa et al., 2013; Silva et al., 2015, Peng et al., 2016; Picke et al., 2016), tornando-o mais suscetível a fraturas (Schwartz et al., 2009; Yamamoto et al., 2009). No estudo de Santana e colaboradores (2003), o diabetes induziu a expressão de 
receptores RAGE e inibiu, em cerca de 40\%, a regeneração de defeitos criados na calvária de camundongos. Outros estudos que realizaram análises microtomográficas da tíbia de ratos (Stolzing et al., 2010) e dos fêmures de ratos e camundongos diabéticos (Tolosa et al., 2013; Peng et al., 2016) mostraram que a hiperglicemia reduziu consideravelmente a qualidade da microestrutura óssea. Outras desordens provocadas pela hiperglicemia foram reportadas por Tolosa e colaboradores (2013), como redução do número de osteócitos, comprometimento do processo de mineralização e da síntese de colágeno tipo I. O estudo de Peng e colaboradores (2016) mostrou ainda que a hiperglicemia reduziu o número de osteoblastos e osteoclastos, inibiu a aposição mineral, a formação e a reabsorção óssea, reduziu o número de vasos sanguíneos e a expressão de marcadores angiogênicos e osteogênicos em CTMs de camundongos diabéticos.

O efeito do diabetes sobre o tecido ósseo tem sido extensivamente discutido em diversos estudos in vitro e in vivo, no entanto, a literatura é escassa em trabalhos que tenham avaliado as desordens provocadas por esta doença no genoma das células, especialmente no que diz respeito a alterações na expressão de genes relacionados com o potencial osteogênico de células osteoprogenitoras. Considerando, portanto, o papel das CTMs no processo de formação e regeneração óssea, este estudo teve por objetivo avaliar a influência do diabetes mellitus nos perfis de expressão gênica em larga escala, por microarray, das células-tronco mesenquimais derivadas da medula óssea de ratos.

\section{Proposição}

O presente trabalho teve por objetivo avaliar, por microarray, a influência do diabetes mellitus sobre a expressão gênica em larga escala de células-tronco mesenquimais isoladas da medula óssea de ratos diabéticos e saudáveis.

\section{Materiais e Métodos}

\subsection{Indução do diabetes mellitus}

Os experimentos foram realizados com 10 ratos machos da linhagem Wistar $(n=5)$ pesando aproximadamente 250 g (CEUA - Comissão de Ética no Uso de Animais: Processo $\mathrm{n}^{\mathrm{o}}$ 2014.1.795.58.0). O diabetes mellitus foi induzido pela administração de estreptozotocina (STZ, Sigma-Aldrich), um agente capaz de desencadear um processo auto-imune que leva à destruição das células tipo $\beta$ das Ilhotas de Langerhans, produtoras de insulina (Akbarzadeh et al., 2007) 
Para a indução do diabetes, os ratos do grupo experimental $(\mathrm{n}=5)$ receberam uma única injeção intraperitoneal de STZ, na dosagem de $60 \mathrm{mg} / \mathrm{Kg}$, diluída em tampão citrato (10 mM, pH 4,5) (Silva et al., 2015). Os ratos do grupo controle $(\mathrm{n}=5)$ receberam uma única injeção intraperitoneal do veículo tampão citrato $(10 \mathrm{mM}, \mathrm{pH} 4,5)$. O diabetes foi confirmado, 72 horas após a injeção, pela dosagem dos níveis de glicose sanguínea utilizando um glicosímetro (AccuCheck ${ }^{\circledR}$ GO, Roche Diagnostics). Foram considerados diabéticos os animais que apresentaram níveis de glicose sanguínea iguais ou superiores a $300 \mathrm{mg} / \mathrm{dL}$, já que os valores considerados normais para a espécie situam-se abaixo de $135 \mathrm{mg} / \mathrm{dL}$. Durante o período experimental, os ratos diabéticos e saudáveis foram tratados com água e ração ad libitum e a glicemia foi avaliada semanalmente. Decorridas 9 semanas da injeção, os animais foram sacrificados para a obtenção das CTMs.

\subsection{Obtenção e cultura de células-tronco mesenquimais derivadas da medula óssea}

Os procedimentos para obtenção e cultura das células foram realizados no Biotério e no Laboratório de Cultura de Células da Faculdade de Odontologia de Ribeirão Preto da Universidade de São Paulo.

As células-tronco mesenquimais foram obtidas da medula óssea dos fêmures dos ratos diabéticos e saudáveis. Para isso, os animais foram submetidos à eutanásia por inalação de Isoflurano ${ }^{\circledR}$ (Instituto Biochimico Ind. Farm. Ltda, RJ, Brasil). Em seguida, os fêmures foram retirados e transportados em meio de cultura contendo meio essencial mínimo modificação alfa ( $\alpha$-MEM) (Gibco-Life Technologies, EUA) suplementado com $500 \mu \mathrm{g} / \mathrm{mL}$ de gentamicina (Gibco-Life Technologies) e $3 \mu \mathrm{g} / \mathrm{mL}$ de fungisona (Gibco-Life Technologies). No fluxo laminar, os fêmures foram submetidos à antissepsia e à remoção de tecidos moles remanescentes. As epífises foram removidas e, a medula óssea, extraída por irrigação com meio de crescimento contendo $\alpha$-MEM suplementado com $10 \%$ de soro fetal bovino (Gibco-Life Technologies), $50 \mu \mathrm{g} / \mathrm{mL}$ de gentamicina (Gibco-Life Technologies) e 0,3 $\mu \mathrm{g} / \mathrm{mL}$ de fungisona (Gibco-Life Technologies). As células da medula óssea foram cultivadas em meio de crescimento (condição não indutora de diferenciação celular), em frascos de 75 $\mathrm{cm}^{2}$ (Corning Incorporated, EUA), para permitir a seleção das células-tronco mesenquimais por aderência ao poliestireno. As culturas foram mantidas a $37^{\circ} \mathrm{C}$ em atmosfera umidificada contendo $5 \%$ de $\mathrm{CO}_{2}$ e $95 \%$ de ar atmosférico, até atingirem a subconfluência. As trocas do meio de cultura foram realizadas a cada 48 horas. 


\subsection{Extração do RNA total das CTMs}

Ao atingir a subconfluência, as culturas de CTMs obtidas da medula óssea dos ratos diabéticos e saudáveis foram tripsinizadas e o RNA total das amostras foi isolado utilizando o kit mirVana ${ }^{\mathrm{TM}}$ (miRNA Isolation Kit, Invitrogen, Termo Fisher Scientific), seguindo o protocolo especificado pelo fabricante. Em seguida, as amostras de RNA foram armazenadas em freezer a $-80^{\circ} \mathrm{C}$.

\subsection{Quantificação e avaliação da integridade do RNA total}

A quantificação e a avaliação da pureza das amostras de RNA total foram realizadas utilizando o NanoVue Plus Spectrophotometer (GE Healthcare, United Kingdon). A integridade das amostras de RNA total foi analisada por meio do sistema de eletroforese microfluídica utilizando o Agilent RNA 6000 Nano Kit e o Agilent 2100 Bioanalyzer (Agilent Technologies, Santa Clara, CA, USA). Para isso, as amostras de RNA foram diluídas e, de cada amostra, foram utilizados $200 \mathrm{ng}$ de RNA total para a amplificação do RNA mensageiro (mRNA). Antes do preparo do chip, os reagentes do kit foram deixados a temperatura ambiente por 30 minutos. Decorridos os 30 minutos, $1 \mu \mathrm{L}$ do RNA 6000 Nano Dye foi pipetado em uma alíquota de $65 \mu \mathrm{L}$ de RNA 600 Nano Gel. Essa mistura foi agitada em vortex por 10 segundos e centrifugada a 13.000 x g, por 10 minutos, à temperatura ambiente. Em seguida, o RNA 6000 Nano Chip foi inserido no priming station e $9 \mu \mathrm{L}$ da mistura gel/dye foram pipetados no poço do chip indicado pela letra "G". A mistura gel/dye foi distribuída por todo chip com o auxílio de uma seringa acoplada ao priming station. Após esse procedimento, $9 \mu \mathrm{L}$ da mistura gel/dye foram pipetados nos demais poços do chip indicados com a letra "G". Na sequência, $1 \mu \mathrm{L}$ do marcador (ladder) foi pipetado no respectivo poço e $5 \mu \mathrm{L}$ do RNA 6000 Nano Marker foram pipetados nos poços das amostras e no poço do ladder. Por fim, foi pipetado $1 \mu \mathrm{L}$ de cada amostra nos respectivos poços, numerados de 1 a 12. Em seguida, o chip foi agitado horizontalmente no vortex IKA MS 3 (Manca, Hong Kong, China) por 1 minuto, a 2200 rpm. Imediatamente após, o chip foi inserido no aparelho Bioanalyzer 2100 Agilent e a leitura foi realizada pelo software da Agilent 2100 Expert. O software calcula o RNA Integrity Number (RIN), que varia de 0 a 10, conforme a qualidade da integridade do RNA. Após a avaliação da integridade do RNA, as amostras foram armazenadas em freezer a $-80^{\circ} \mathrm{C}$ até o momento das análises por microarray.

\subsection{Oligo Microarray}

A análise genômica foi realizada no Laboratório de Imunogenética Molecular da Faculdade de Medicina de Ribeirão Preto da Universidade de São Paulo. Foram utilizados 
microarrays Agilent 4x44k, contendo 44.000 oligonucleotídeos, sintetizados e fixados na superfície das lâminas através do sistema de impressão (SurePrint), utilizando sequências de RNA mensageiro obtidas de arquivos disponíveis em banco de dados. A marcação e a amplificação do RNA foram realizadas seguindo as especificações do One-Color MicroarrayBased Gene Expression Analysis (Low Input Quick Amp Labeling) Protocol da Agilent. Os experimentos foram realizados em triplicata para as amostras de CTMs obtidas dos ratos diabéticos e saudáveis.

\subsubsection{Preparo das amostras}

Primeiramente, foi realizado o preparo e a diluição do Spike Mix. O Spike Mix foi agitado em vortex, aquecido a $37^{\circ} \mathrm{C}$ por 5 minutos, novamente agitado e centrifugado por alguns segundos. Após esses procedimentos, foram realizadas 3 diluições seriadas do Spike Mix (1:20; 1:25 e 1:10), conforme o descrito no protocolo da Agilent para uma massa de RNA total de $200 \mathrm{ng}$. Após as diluições, $200 \mathrm{ng}$ de RNA total em um volume de 1,5 $\mu \mathrm{L}$ foram colocados em tubos de 1,5 mL. Em cada tubo, foram adicionados $2 \mu \mathrm{L}$ de Spike Mix diluído, perfazendo um volume final de 3,5 $\mu \mathrm{L}$. Em seguida, foram adicionados 1,8 $\mu \mathrm{L}$ de T7 Primer Mix diluído em cada tubo de amostra, os quais foram incubadas em banho-maria, a $65^{\circ} \mathrm{C}$, por 10 minutos. Após serem retiradas do banho, as amostras foram colocadas no gelo por 5 minutos.

\subsubsection{Síntese do cDNA}

Para a síntese do DNA complementar (cDNA), foi realizado o pré-aquecimento do 5x First Strand Buffer por 4 minutos, a $80^{\circ} \mathrm{C}$, seguida da agitação em vortex e de breve centrifugação. O cDNA Master Mix foi preparado pela adição de $30 \mu \mathrm{L}$ de 5x First Strand Buffer, $15 \mu \mathrm{L}$ de 0,1 M de DTT, 7,5 $\mu \mathrm{L}$ de $10 \mathrm{mM}$ de dNTP Mix e $18 \mu \mathrm{L}$ de Affinity Script RNase Block Mix. O volume de cada reagente foi calculado com base no número de reações, conforme as proporções especificadas pelo protocolo da Agilent. Após breve centrifugação, 4,7 $\mu \mathrm{L}$ do cDNA Master Mix foram adicionados em cada tubo de amostra, os quais foram incubados em banho-maria, a $40^{\circ} \mathrm{C}$, por 2 horas. Após esse período, as amostras foram transferidas para o banho-maria, a $70^{\circ} \mathrm{C}$, por 15 minutos. Em seguida, as amostras foram colocadas no gelo por 5 minutos e centrifugadas brevemente. 


\subsubsection{Síntese, amplificação e marcaçãodo cRNA}

O preparo do Transcription Master Mix para síntese e amplificação do RNA complementar (cRNA) foi realizado pela adição de 11,25 $\mu \mathrm{L}$ de Nuclease-Free Water, $48 \mu \mathrm{L}$ de 5x Transcription Buffer, $9 \mu \mathrm{L}$ de 0,1 M de DTT, $15 \mu \mathrm{L}$ de NTP Mix, 3,15 $\mu \mathrm{L}$ de T7 RNA Polymerase Blend e 3,6 $\mu \mathrm{L}$ de Cyanine 3-CTP. O volume de cada reagente foi calculado com base no número de reações, conforme as proporções especificadas pelo protocolo da Agilent. Após breve centrifugação, $6 \mu \mathrm{L}$ do Transcription Master Mix foram adicionados em cada tubo de amostra, os quais foram incubados em banho-maria, a $40^{\circ} \mathrm{C}$, por 2 horas.

\subsubsection{Purificação do cRNA}

Para purificação do cRNA foi utilizado o Illustra ${ }^{\mathrm{TM}}$ RNAspin Mini Isolation Kit (GE Healthcare Life Sciences). Primeiramente, foram adicionados $56 \mu \mathrm{L}$ do tampão RA1 em cada tubo da amostra, seguida da adição de $56 \mu \mathrm{L}$ de álcool 100\%. Em seguida, as amostras foram transferidas para as colunas do kit Illustra ${ }^{\mathrm{TM}}$ e centrifugadas a $8.000 \mathrm{rpm}$, a $4^{\circ} \mathrm{C}$, por 30 segundos. Após a centrifugação, os tubos coletores foram descartados e as colunas foram transferidas para tubos novos. Em seguida, foi realizado uma nova lavagem, adicionando tampão RA3 em cada coluna, seguida de centrifugação a $11.000 \mathrm{rpm}$, a $4^{\circ} \mathrm{C}$, por 1 minuto. $\mathrm{O}$ líquido do tubo coletor foi descartado e uma nova lavagem da coluna com tampão RA3 foi realizada, seguida de centrifugação a $11.000 \mathrm{rpm}$, a $4^{\circ} \mathrm{C}$, por 3 minutos.

Para eluição do cRNA, foram adicionados $40 \mu \mathrm{L}$ de água livre de nucleases em cada coluna, seguida de centrifugação a $11.000 \mathrm{rpm}$, a $4{ }^{\circ} \mathrm{C}$, por 1 minuto.

\subsubsection{Quantificação do cRNA}

A quantificação do cRNA $(\mathrm{ng} / \mu \mathrm{L})$ de cada amostra foi realizada utilizando o espectrofotômetro NanoDrop ND-1000 UV-VIS (NanoDrop Technologies). Foram obtidas ainda a concentração de cianina $3(\mathrm{pmol} / \mu \mathrm{L})$, necessárias para avaliação da eficácia da incorporação desse fluorocromo no cRNA.

\subsubsection{Hibridização}

Em cada tubo de amostra contendo $1,65 \mu \mathrm{g}$ de cRNA, foram adicionados $11 \mu \mathrm{L}$ de 10x Gene Expression Blocking Agent e 2,2 $\mu \mathrm{L}$ de 25x Fragmentation Buffer. Em seguida, as amostras foram incubadas a $60^{\circ} \mathrm{C}$, por 30 minutos, para fragmentação do cRNA. Decorridos os 30 minutos, as amostras foram colocadas no gelo por 1 minuto. Logo após, foram adicionados $55 \mu \mathrm{L}$ de Hi-RPM Hybridization Buffer em cada tubo de amostra. Para o 
processo de hibridização, foram colocados $100 \mu \mathrm{L}$ de cada amostra em cada campo da lâmina. As lâminas de microarray foram levadas ao forno de hibridização, onde permaneceram em rotação de $10 \mathrm{rpm}$, por 17 horas, a $65^{\circ} \mathrm{C}$.

\subsubsection{Lavagem das lâminas de microarray}

Após o processo de hibridização, as lâminas foram lavadas por 1 minuto em GE Wash Buffer 1 (contendo 0,005\% Triton X-102), à temperatura ambiente. Em seguida, as lâminas foram lavadas por 1 minuto em GE Wash Buffer 2 (contendo 0,005\% Triton X-102), a $37^{\circ} \mathrm{C}$. Na sequência, as lâminas foram colocadas em solução de acetonitrila por 10 segundos e em solução de Stabilization and Drying por 30 segundos, à temperatura ambiente. A utilização do Stabilization and Drying tem por finalidade prevenir a degradação da cianina 3 pelo ozônio. As soluções utilizadas nessas etapas permaneceram sob agitação constante durante todo o procedimento.

\subsubsection{Escaneamento e extração dos dados}

Após os procedimentos de lavagens, as lâminas foram imediatamente escaneadas utilizando o DNA Microarray Scanner (Agilent Technologies) e os dados foram extraídos utilizando o Agilent Feature Extraction Software.

\subsubsection{Análise dos dados do microarray}

A análise da modulação dos genes diferencialmente expressos entre as CTMs obtidas dos ratos diabéticos e saudáveis foi realizada pelo software GeneSpring 14.9 GX (Agilent Technologies, Santa Clara, CA, USA). Os dados foram normalizados por percentil $75 \%$ e a análise estatística foi realizada utilizando o Test-T não pareado, considerando o valor de $\mathrm{p} \leq 0,05$. Para análise da modulação dos genes diferencialmente expressos entre os dois grupos de CTMs, foi adotado um fold-change $\geq 2,0$. O agrupamento hierárquico dos dados (clustering) foi realizado utilizando a medida de distância euclidiana (centroide) para expressar a dissimilaridade entre os grupos.

A análise funcional dos genes diferencialmente expressos foi realizada pela database DAVID (Database for Annotation, Visualization and Integrated Discovery) Functional Annotation Bioinformatics Microarray Analysis (https://david.ncifcrf.gov). Os

genes diferencialmente expressos foram inseridos na database DAVID e agrupados por processo biológico (Functional Annotation Clustering - Gene Ontology), considerando um valor de $\mathrm{p} \leq 0,05$. 


\subsubsection{Confirmação dos dados por PCR em tempo real}

Os dados obtidos pelo microarray foram confirmados por PCR em tempo real. Foram avaliados os genes Bmp4 (bone morphogenetic protein 4), Sppl(secreted phosphoprotein 1), $K d r$ (kinase insert domain receptor) e Pecaml (platelet and endothelial cell adhesion molecule 1). O PCR em tempo real foi realizado utilizando sondas TaqMan (Applied Biosystems, EUA) e o aparelho Step One Plus (Life Technologies, Carlsbad, Califórnia, EUA). As reações foram realizadas em triplicata $(\mathrm{n}=3)$, utilizando $5 \mu \mathrm{L}$ de Taqman Gene Expression Master Mix, 0,5 $\mu \mathrm{L}$ de Sonda TaqMan e 4,5 $\mu \mathrm{L}$ de cDNA, para um volume final de $10 \mu \mathrm{L}$ por reação. Uma amostra de água (blank) foi submetida à reação com cada sonda TaqMan utilizada. As reações de amplificação compreenderam 2 minutos a $50^{\circ} \mathrm{C}$, 10 minutos a $95^{\circ} \mathrm{C}, 45$ ciclos de 15 segundos a $95^{\circ} \mathrm{C}$ e 1 minuto a $60^{\circ} \mathrm{C}$. Os resultados foram avaliados considerando o valor de $\mathrm{Ct}$ (Cycle Threshold). O gene de referência Gapdh (glyceraldehyde-3-phosphate dehydrogenase) foi utilizado para a normalização dos dados. A normalização e quantificação relativa da expressão gênica foram realizadas pelo método de $2^{-}$ $\triangle \triangle \mathrm{CT}$ (Livak et al., 2001). A análise estatística dos dados foi realizada pelo SigmaPlot 14 Scientific Graphing and Statistical Analysis Software, considerando o valor de $p \leq 0,05$.

\section{Resultados}

\subsection{Dosagem dos níveis de glicose sanguínea}

Os ratos do grupo controle que receberam a injeção do veículo tampão citrato apresentaram níveis glicêmicos inferiores a $135 \mathrm{mg} / \mathrm{dL}$, enquanto que, os ratos que receberam a injeção de STZ diluída em tampão citrato apresentaram níveis de glicose sanguínea superiores a $300 \mathrm{mg} / \mathrm{dL}$ (Figura 1). 


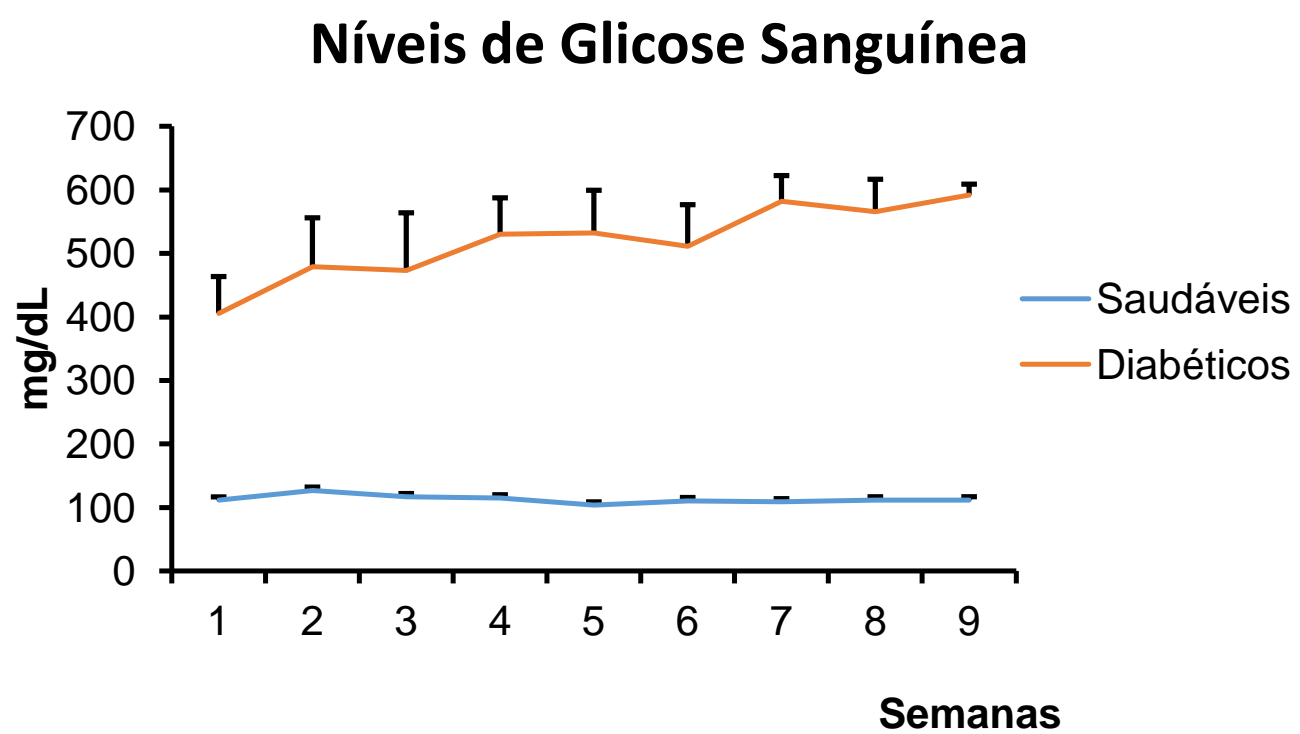

Figura 1 - Dosagens dos níveis de glicose sanguínea dos ratos diabéticos e saudáveis, realizadas após o procedimento de injeção, em função do tempo (média \pm desvio padrão).

\subsection{Avaliação da integridade do RNA total}

A qualidade do RNA total de cada amostra foi avaliada pela integridade das bandas de RNAr 28S, RNAr 18S e RNAr 5S, obtidas por eletroforese microfluídica, e pelo valor de RIN (RNA Integrity Number), calculado pela densitometria do RNA. Os resultados da eletroforese (Figura 2) e da densitometria (Figura 3), obtidos pelo Agilent 2100 Expert Software, mostraram que todas as amostras de RNA total apresentaram-se íntegras, com valores de RIN entre 8,7 e 9,5. 
[nt]

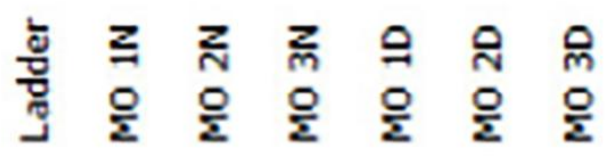

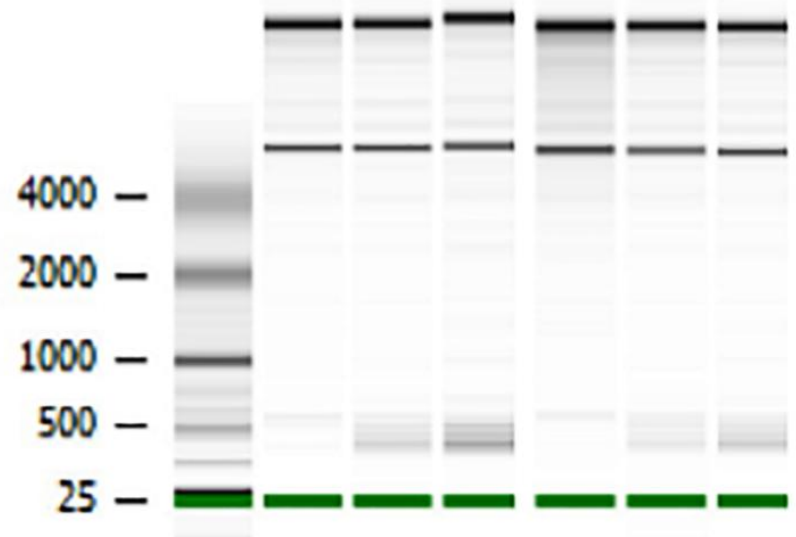

Figura 2 - Eletroforese microfluídica da triplicata das amostras de CTMs obtidas da medula óssea (MO) dos ratos saudáveis $(1 \mathrm{~N}, 2 \mathrm{~N}$ e $3 \mathrm{~N})$ e dos ratos diabéticos (1D, 2D e 3D).
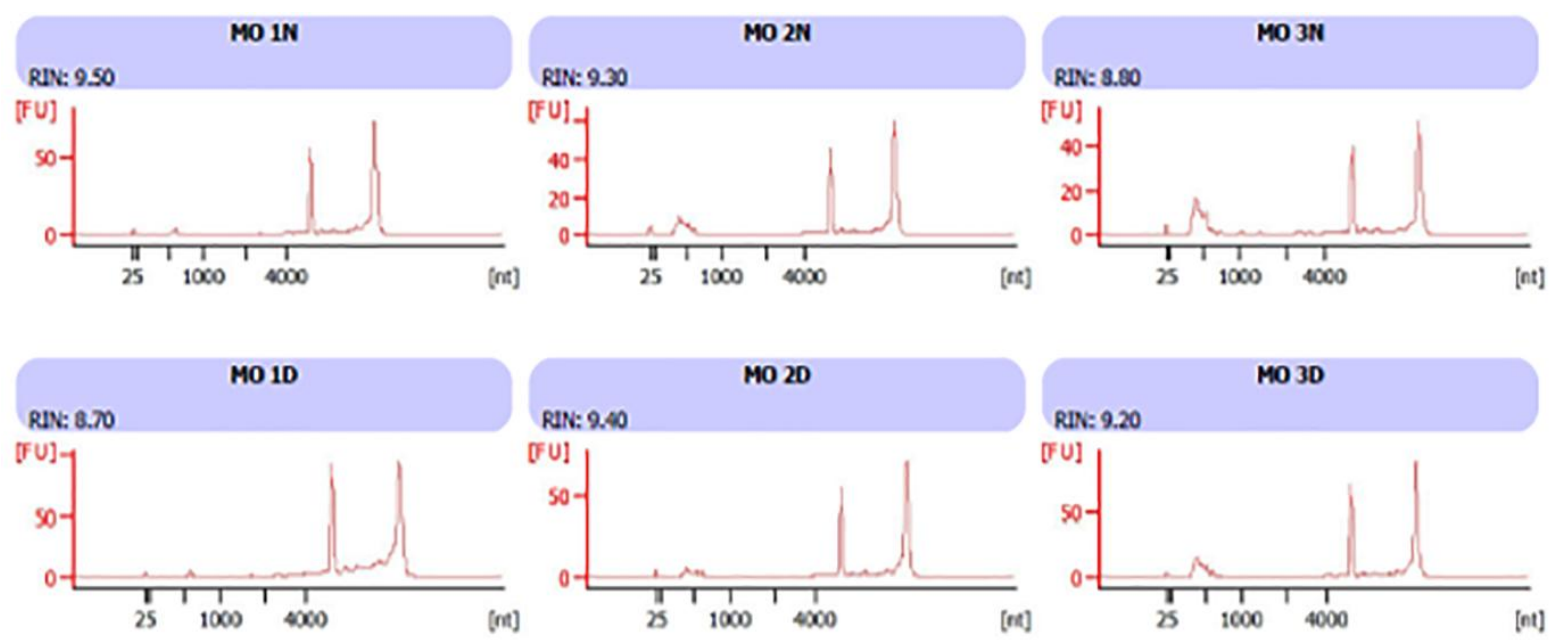

Figura 3 - Densitometria da eletroforese microfluídica da triplicata das amostras de CTMs obtidas da medula óssea (MO) dos ratos saudáveis (1N, 2N e 3N) e dos ratos diabéticos (1D, 2D e 3D). 


\subsection{Análises dos mRNAs diferencialmente expressos}

A modulação dos genes diferencialmente expressos entre os grupos é apresentada pelo heat map (Figura 4), no qual os grupos e os genes apresentam-se agrupados de forma hierárquica por dendrograma. As linhas do dendrograma estão ligadas segundo o grau de similaridade entre os perfis de expressão gênica dos grupos (clustering) e as cores mostram as diferenças na modulação da expressão gênica, considerando um fold-change $\geq 2,0$.

O dendrograma mostra que as CTMs obtidas da medula óssea dos ratos diabéticos e saudáveis estão agrupadas no mesmo cluster, devido às similaridades encontradas nos perfis de expressão gênica. No entanto, as cores mostram diferenças na modulação da expressão de diversos grupos de genes. O vermelho representa os genes induzidos, o azul representa os genes reprimidos e, o amarelo, os genes não modulados. Os dados são apresentados como média da triplicata experimental (Figura 4).

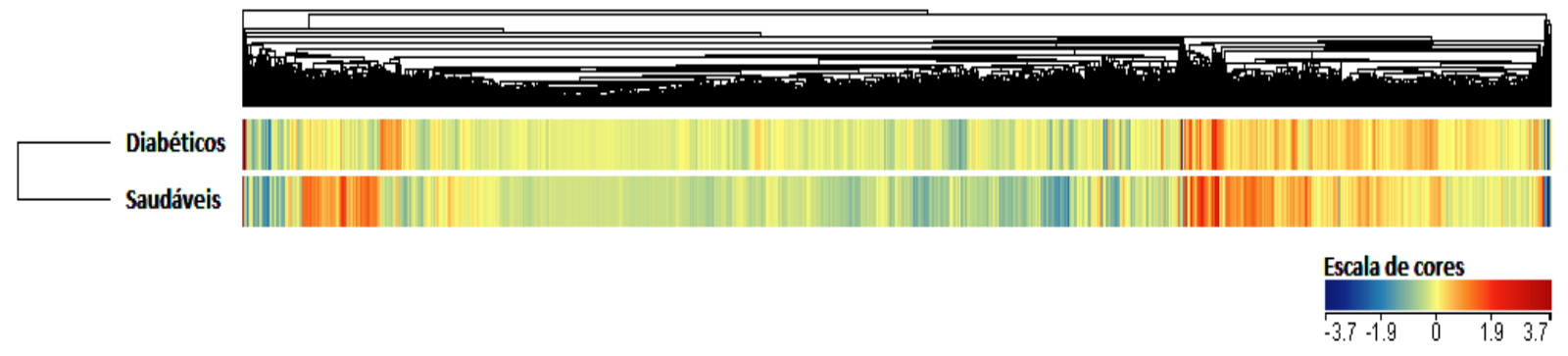

Figura 4 - Agrupamento hierárquico dos genes diferencialmente expressos nas amostras de CTMs obtidas da medula óssea dos ratos diabéticos e dos ratos saudáveis. O vermelho representa indução, o azul representa repressão e, o amarelo, não modulação. Fonte: GeneSpring 14.9 GX Software.

Considerando os genes diferencialmente expressos, as CTMs dos ratos diabéticos apresentaram, em relação às CTMs dos ratos saudáveis, 848 genes induzidos e 1122 genes reprimidos (arquivo completo disponível em CD-ROM - Anexo A). Os genes mais modulados são apresentados nas Tabelas 1 e 2 (induzidos e reprimidos, respectivamente).

Tabela 1 - Lista dos 20 genes mais modulados no grupo das CTMs dos ratos diabéticos em relação às CTMs dos ratos saudáveis: genes induzidos.

\begin{tabular}{llr}
\hline Genes & Descrição & Fold-Change \\
\hline Rhox5 & reproductive homeobox 5 & $+26,21$ \\
Olr1592 & olfactory receptor 1592 & $+15,58$ \\
Adam24 & ADAM metallopeptidase domain 24 & $+11,54$ \\
Tnfrsf17 & TNF receptor superfamily member 17 & $+11,14$ \\
\hline
\end{tabular}




\begin{tabular}{llc}
\hline Fcerla & Fc fragment of IgE receptor Ia & $+11,14$ \\
H19 & H19, imprinted maternally expressed transcript & $+10,86$ \\
Plvap & plasmalemma vesicle associated protein & $+10,21$ \\
Ms4a12 & membrane spanning 4-domains A12 & $+9,64$ \\
Erg & ERG, ETS transcription factor & $+8,21$ \\
Jchain & joining chain of multimeric IgA and IgM & $+7,89$ \\
Fcrla & Fc receptor-like A & $+6,78$ \\
Epha4 & Eph receptor A4 & $+6,43$ \\
Myh7 & myosin heavy chain 7 & $+6,39$ \\
Cmal & chymase 1 & $+6,16$ \\
Pla2g2a & phospholipase A2 group IIA & $+6,02$ \\
Myct1 & myc target 1 & $+5,81$ \\
Gpr4 & G protein-coupled receptor 4 & $+5,65$ \\
Cldn2 & claudin 2 & $+5,60$ \\
Xpo7 & exportin 7 & $+5,28$ \\
Igf2 & insulin-like growth factor 2 & $+5,25$ \\
\hline
\end{tabular}

Fonte: GeneSpring 14.9 GX.

Tabela 2 - Lista dos 20 genes mais modulados no grupo das CTMs dos ratos diabéticos em relação às CTMs dos ratos saudáveis: genes reprimidos.

\begin{tabular}{llc}
\hline Genes & Descrição & Fold-Change \\
\hline Cl180 & CD180 molecule & $-16,21$ \\
Cldn4 & claudin 4 & $-14,40$ \\
Slco4a1 & solute carrier organic anion transporter family 4a1 & $-11,30$ \\
Fabp4 & fatty acid binding protein 4 & $-10,88$ \\
Atp6v0d2 & ATPase H+ transporting V0 subunit D2 & $-9,99$ \\
Mmp12 & matrix metallopeptidase 12 & $-9,70$ \\
Gpr84 & G protein-coupled receptor 84 & $-9,39$ \\
Clgn & calmegin & $-9,36$ \\
Clec5a & C-type lectin domain containing 5A & $-8,43$ \\
Gsta2 & glutathione S-transferase alpha 2 & $-8,33$ \\
Ch25h & cholesterol 25-hydroxylase & $-8,32$ \\
Spp1 & secreted phosphoprotein 1 & $-8,07$ \\
Gsta4 & glutathione S-transferase alpha 4 & $-7,50$ \\
Cenpm & centromere protein M & $-7,35$ \\
Plau & plasminogen activator, urokinase & $-7,32$ \\
Ill8bp & interleukin 18 binding protein & $-7,22$ \\
Slc7a7 & solute carrier family 7 member 7 & $-7,17$ \\
Ccnb2 & cyclin B2 & $-7,05$ \\
\hline
\end{tabular}




\begin{tabular}{lll}
\hline Tpx2 & TPX2, microtubule nucleation factor & $-6,85$ \\
Ccl4 & C-C motif chemokine ligand 4 & $-6,65$ \\
\hline
\end{tabular}

Fonte: GeneSpring 14.9 GX.

A caracterização funcional dos genes diferencialmente expressos e o enriquecimento de alguns processos biológicos considerados de interesse para o estudo são apresentados na Figura 5. A caracterização funcional refere-se ao agrupamento de um conjunto de genes de acordo com o processo ou função biológica que desempenham. O enriquecimento funcional diz respeito ao número de genes, induzidos e/ou reprimidos, relacionados com um processo biológico específico. A Figura 5 mostra que todos os processos biológicos de interesse foram enriquecidos tanto por genes induzidos como por genes reprimidos. No entanto, os processos de diferenciação de osteoblasto, regulação positiva da mineralização óssea, regulação positiva do transporte do íon cálcio, regulação negativa da diferenciação de osteoclasto, ossificação, processo regenerativo, coagulação sanguínea, resposta imune e metabolismo de glicose foram enriquecidos predominantemente por genes reprimidos. Os processos de angiogênese e de regulação positiva da resposta inflamatória aguda foram enriquecidos predominantemente por genes induzidos. Os processos de regulação positiva da biossíntese de colágeno e regulação positiva da quimiotaxia celular foram igualmente enriquecidos por genes induzidos e reprimidos (Figura 5). 


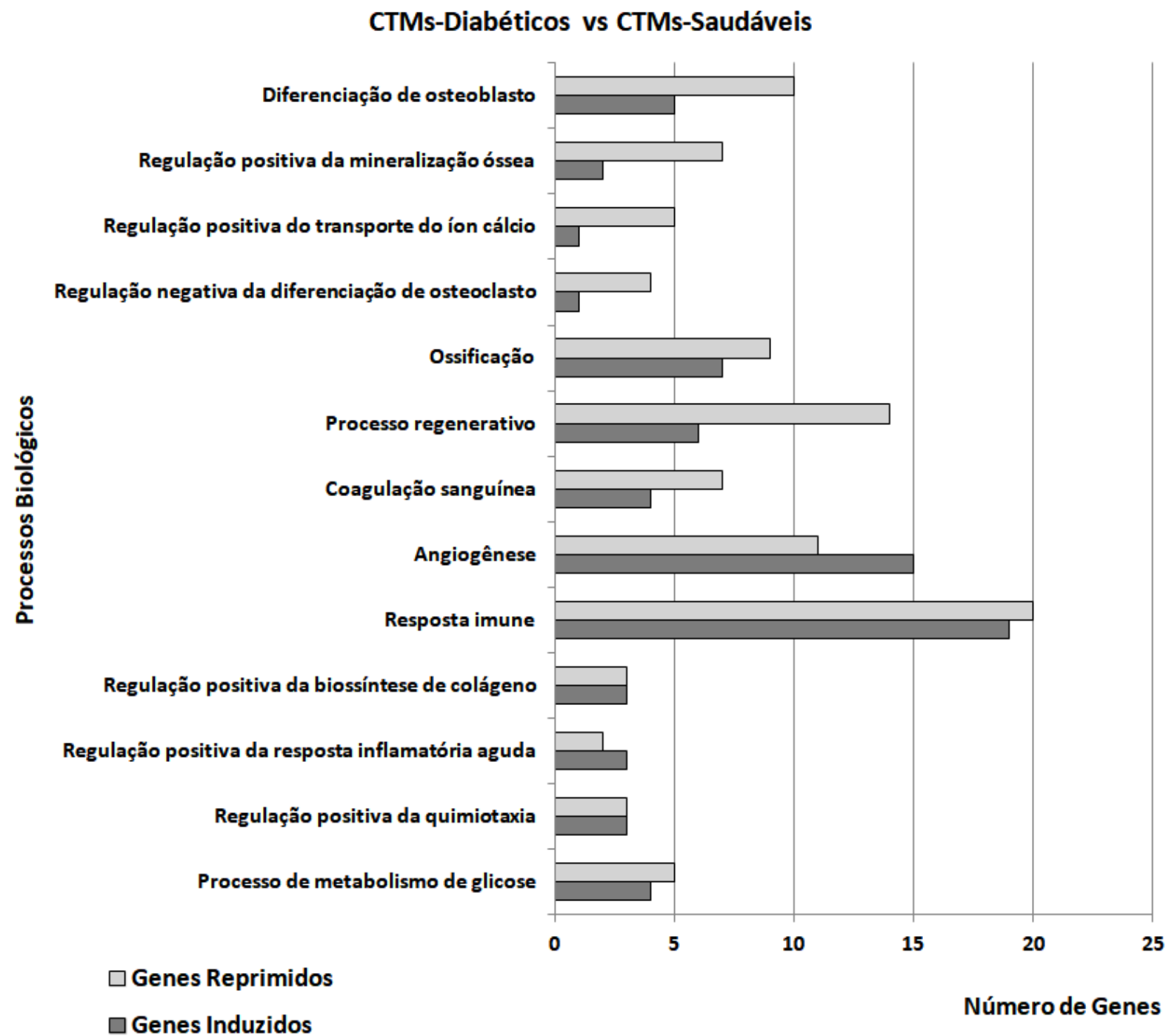

Figura 5 - Enriquecimento funcional dos processos biológicos de interesse por genes induzidos e reprimidos apresentado pelas CTMs dos ratos diabéticos em relação às CTMs dos ratos saudáveis. Fonte: DAVID (Database for Annotation, Visualization and Integrated Discovery).

A modulação dos genes diferencialmente expressos, induzidos e reprimidos, envolvidos com cada processo biológico de interesse é apresentada nas Tabelas 3 a 16. Esses resultados consideram a expressão gênica apresentada pelo grupo das CTMs dos ratos diabéticos em relação às CTMs dos ratos saudáveis. Todos os processos biológicos foram enriquecidos por genes induzidos e por genes reprimidos, no entanto, a análise da modulação da expressão dos genes envolvidos com cada processo biológico de interesse aponta diferenças relevantes entre as CTMs dos ratos diabéticos e saudáveis.

A repressão de genes envolvidos com os processos de diferenciação de osteoblasto, regulação positiva da mineralização óssea, regulação positiva do transporte do 
íon cálcio, regulação negativa da diferenciação de osteoclasto, ossificação, regeneração e coagulação sanguínea foi mais acentuada que a indução, o que sugere que o diabetes pode exercer um efeito inibitório sobre tais processos (Tabelas 3 a 9).

Tabela 3 - CTMs dos ratos diabéticos vs CTMs dos ratos saudáveis: Genes diferencialmente expressos relacionados com o processo de diferenciação osteoblástica.

\begin{tabular}{llc}
\hline Genes & Descrição & Fold-Change \\
\hline Igf2 & insulin-like growth factor 2 & $+5,25$ \\
Ihh & Indian hedgehog & $+2,29$ \\
Bmp4 & bone morphogenetic protein 4 & $+2,28$ \\
Myoc & myocilin & $+2,23$ \\
Bmp8a & bone morphogenetic protein 8a & $+2,10$ \\
Spp1 & secreted phosphoprotein 1 & $-8,07$ \\
Lef1 & lymphoid enhancer binding factor 1 & $-3,47$ \\
Ibsp & integrin-binding sialoprotein & $-2,88$ \\
Tnc & tenascin C & $-2,86$ \\
Igfbp3 & insulin-like growth factor binding protein 3 & $-2,83$ \\
Msx2 & msh homeobox 2 & $-2,78$ \\
Twist2 & twist family bHLH transcription factor 2 & $-2,41$ \\
Ccl3 & C-C motif chemokine ligand 3 & $-2,37$ \\
Gpnmb & glycoprotein nmb & $-2,28$ \\
Bmp7 & bone morphogenetic protein 7 & $-2,08$ \\
\hline Fonte: Genp &
\end{tabular}

Fonte: GeneSpring 14.9 GX/DAVID (Database for Annotation, Visualization and Integrated Discovery).

Tabela 4 - CTMs dos ratos diabéticos vs CTMs dos ratos saudáveis: Genes diferencialmente expressos relacionados com o processo de regulação positiva da mineralização óssea.

\begin{tabular}{llc}
\hline Genes & Descrição & Fold-Change \\
\hline Gpm6b & glycoprotein m6b & $+2,51$ \\
Bmp4 & bone morphogenetic protein 4 & $+2,28$ \\
Fam20c & FAM20C, golgi associated secretory pathway kinase & $-2,34$ \\
Acvr2b & activin A receptor type 2B & $-2,30$ \\
Fbn2 & fibrillin 2 & $-2,18$ \\
Tgfb1 & transforming growth factor, beta 1 & $-2,10$ \\
Bmp7 & bone morphogenetic protein 7 & $-2,08$ \\
Bmpr2 & bone morphogenetic protein receptor type 2 & $-2,04$ \\
Tgfb3 & transforming growth factor, beta 3 & $-2,03$ \\
\hline
\end{tabular}

Fonte: GeneSpring 14.9 GX/DAVID (Database for Annotation, Visualization and Integrated Discovery). 
Tabela 5 - CTMs dos ratos diabéticos vs CTMs dos ratos saudáveis: Genes diferencialmente expressos relacionados com a regulação positiva do transporte do íon cálcio.

\begin{tabular}{clr}
\hline Genes & Descrição & Fold-Change \\
\hline Stim2 & stromal interaction molecule 2 & $+2,22$ \\
Ccl4 & C-C motif chemokine ligand 4 & $-6,65$ \\
Trpc6 & transient receptor potential cation channel, subfamily C, member 6 & $-3,26$ \\
Orail & ORAI calcium release-activated calcium modulator 1 & $-2,88$ \\
Ccl3 & C-C motif chemokine ligand 3 & $-2,37$ \\
Ccr1 & C-C motif chemokine receptor 1 & $-2,22$ \\
\hline
\end{tabular}

Fonte: GeneSpring 14.9 GX/DAVID (Database for Annotation, Visualization and Integrated Discovery).

Tabela 6 - CTMs dos ratos diabéticos vs CTMs dos ratos saudáveis: Genes diferencialmente expressos relacionados com a regulação negativa da diferenciação osteoclástica.

\begin{tabular}{llc}
\hline Genes & Descrição & Fold-Change \\
\hline Sfrpl & secreted frizzled-related protein 1 & $+3,27$ \\
Fstl3 & follistatin like 3 & $-2,93$ \\
Inpp5d & inositol polyphosphate-5-phosphatase D & $-2,66$ \\
Ccl3 & C-C motif chemokine ligand 3 & $-2,37$ \\
Lilrb4 & leukocyte immunoglobulin like receptor B4 & $-2,02$ \\
\hline
\end{tabular}

Fonte: GeneSpring 14.9 GX/DAVID (Database for Annotation, Visualization and Integrated Discovery).

Tabela 7 - CTMs dos ratos diabéticos vs CTMs dos ratos saudáveis: Genes diferencialmente expressos relacionados com o processo de ossificação.

\begin{tabular}{llc}
\hline Genes & Descrição & Fold-Change \\
\hline Igf2 & insulin-like growth factor 2 & $+5,25$ \\
Rsad2 & radical S-adenosyl methionine domain containing 2 & $+4,02$ \\
Cacnals & calcium voltage-gated channel subunit alpha1 S & $+2,93$ \\
Gpm6b & glycoprotein m6b & $+2,51$ \\
Ihh & Indian hedgehog & $+2,29$ \\
Rassf2 & Ras association domain family member 2 & $+2,19$ \\
Smad5 & SMAD family member 5 & $+2,06$ \\
Spp1 & secreted phosphoprotein 1 & $-8,07$ \\
Mmp9 & matrix metallopeptidase 9 & $-5,85$ \\
Acan & aggrecan & $-4,92$ \\
Fstl3 & follistatin like 3 & $-2,93$ \\
Ibsp & integrin-binding sialoprotein & $-2,88$ \\
Msx2 & msh homeobox 2 & $-2,78$ \\
Ostn & osteocrin & $-2,72$ \\
Slc34al & solute carrier family 34 member 1 & $-2,62$ \\
Pdlim7 & PDZ and LIM domain 7 & $-2,14$ \\
\hline
\end{tabular}


Fonte: GeneSpring 14.9 GX/DAVID (Database for Annotation, Visualization and Integrated Discovery).

Tabela 8 - CTMs dos ratos diabéticos vs CTMs dos ratos saudáveis: Genes diferencialmente expressos relacionados com o processo regenerativo.

\begin{tabular}{|c|c|c|}
\hline Genes & Descrição & Fold-Change \\
\hline $\operatorname{Igf2}$ & insulin-like growth factor 2 & $+5,25$ \\
\hline Pecam1 & platelet and endothelial cell adhesion molecule 1 & $+3,77$ \\
\hline Il6 & interleukin 6 & $+3,34$ \\
\hline Grhl3 & grainyhead-like transcription factor 3 & $+2,53$ \\
\hline$P 2 r y 1$ & purinergic receptor $\mathrm{P} 2 \mathrm{Y} 1$ & $+2,38$ \\
\hline Bmp4 & bone morphogenetic protein 4 & $+2,28$ \\
\hline Mmp12 & matrix metallopeptidase 12 & $-9,70$ \\
\hline Plau & plasminogen activator, urokinase & $-7,32$ \\
\hline S100a8 & S100 calcium binding protein $\mathrm{A} 8$ & $-3,60$ \\
\hline Slcllal & solute carrier family 11 member 1 & $-3,50$ \\
\hline Mustn1 & musculoskeletal, embryonic nuclear protein 1 & $-3,31$ \\
\hline $\operatorname{Tnc}$ & tenascin $\mathrm{C}$ & $-2,86$ \\
\hline$C d h 3$ & cadherin 3 & $-2,78$ \\
\hline$F c g r 3 a$ & Fc fragment of IgG receptor IIIa & $-2,71$ \\
\hline$P 2 r y 2$ & purinergic receptor $\mathrm{P} 2 \mathrm{Y} 2$ & $-2,70$ \\
\hline$M s x 2$ & msh homeobox 2 & $-2,78$ \\
\hline Illa & interleukin 1 alpha & $-2,21$ \\
\hline Mmp3 & matrix metallopeptidase 3 & $-2,11$ \\
\hline$T g f b 1$ & transforming growth factor, beta 1 & $-2,10$ \\
\hline$T g f b 3$ & transforming growth factor, beta 3 & $-2,03$ \\
\hline
\end{tabular}

Fonte: GeneSpring 14.9 GX/DAVID (Database for Annotation, Visualization and Integrated Discovery).

Tabela 9 - CTMs dos ratos diabéticos vs CTMs dos ratos saudáveis: Genes diferencialmente expressos relacionados com o processo de coagulação sanguínea.

\begin{tabular}{llr}
\hline Genes & Descrição & Fold-Change \\
\hline Shh & sonic hedgehog & $+2,31$ \\
Hnf4a & hepatocyte nuclear factor 4, alpha & $+2,21$ \\
Serping1 & serpin family G member 1 & $+2,17$ \\
Vwf & von Willebrand factor & $+2,14$ \\
F2rl2 & coagulation factor II (thrombin) receptor-like 2 & $-5,96$ \\
C3 & complement C3 & $-2,86$ \\
Anxa8 & annexin A8 & $-2,68$ \\
Anxa5 & annexin A5 & $-2,60$ \\
Procr & protein C receptor & $-2,29$ \\
\hline
\end{tabular}




\begin{tabular}{llr}
\hline Apoh & apolipoprotein H & $-2,05$ \\
F3 & coagulation factor III, tissue factor & $-2,05$ \\
\hline
\end{tabular}

Fonte: GeneSpring 14.9 GX/DAVID (Database for Annotation, Visualization and Integrated Discovery).

Por outro lado, a indução de genes envolvidos com os processos de angiogênese e de resposta imune foi mais acentuada que a repressão, o que sugere que, dentro do período experimental considerado no estudo, esses processos podem ser exacerbados pelo diabetes (Tabelas 10 e 11).

Tabela 10 - CTMs dos ratos diabéticos vs CTMs dos ratos saudáveis: Genes diferencialmente expressos relacionados com o processo de angiogênese.

\begin{tabular}{|c|c|c|}
\hline Genes & Descrição & Fold-Change \\
\hline$K d r$ & kinase insert domain receptor & $+4,09$ \\
\hline Eln & elastin & $+3,87$ \\
\hline Esml & endothelial cell-specific molecule 1 & $+3,82$ \\
\hline Pecaml & platelet and endothelial cell adhesion molecule 1 & $+3,77$ \\
\hline Angptl4 & angiopoietin-like 4 & $+3,23$ \\
\hline Angpt1 & angiopoietin 1 & $+3,14$ \\
\hline Rspo3 & R-spondin 3 & $+3,09$ \\
\hline Rasip1 & Ras interacting protein 1 & $+2,82$ \\
\hline Nrxnl & neurexin 1 & $+2,58$ \\
\hline Rampl & receptor activity modifying protein 1 & $+2,51$ \\
\hline Meox2 & mesenchyme homeobox 2 & $+2,48$ \\
\hline$V e g f c$ & vascular endothelial growth factor $\mathrm{C}$ & $+2,34$ \\
\hline Shh & sonic hedgehog & $+2,31$ \\
\hline Ptprb & protein tyrosine phosphatase, receptor type, B & $+2,30$ \\
\hline Pik3ca & phosphatidylinositol-4,5-bisphosphate 3-kinase, catalytic subunit alpha & $+2,07$ \\
\hline Klf5 & Kruppel-like factor 5 & $-4,10$ \\
\hline Ccl12 & chemokine (C-C motif) ligand 12 & $-3,76$ \\
\hline Adam8 & ADAM metallopeptidase domain 8 & $-3,15$ \\
\hline Plxnd1 & plexin D1 & $-2,91$ \\
\hline Anpep & alanyl aminopeptidase, membrane & $-2,83$ \\
\hline$T g f b i$ & transforming growth factor, beta induced & $-2,75$ \\
\hline Flna & filamin A & $-2,35$ \\
\hline Ackr3 & atypical chemokine receptor 3 & $-2,15$ \\
\hline Mfge8 & milk fat globule-EGF factor 8 protein & $-2,09$ \\
\hline Gja5 & gap junction protein, alpha 5 & $-2,06$ \\
\hline Ndnf & neuron-derived neurotrophic factor & $-2,04$ \\
\hline
\end{tabular}

Fonte: GeneSpring 14.9 GX/DAVID (Database for Annotation, Visualization and Integrated Discovery). 
Tabela 11 - CTMs dos ratos diabéticos vs CTMs dos ratos saudáveis: Genes diferencialmente expressos relacionados com o processo de resposta imune.

\begin{tabular}{|c|c|c|}
\hline Genes & Descrição & $\begin{array}{l}\text { Fold-Change } \\
\end{array}$ \\
\hline Fcerla & Fc fragment of IgE receptor Ia & $+11,14$ \\
\hline Cmal & chymase 1 & $+6,16$ \\
\hline$C 7$ & complement $\mathrm{C} 7$ & $+4,50$ \\
\hline Mcpt10 & mast cell protease 10 & $+3,87$ \\
\hline Mcpt8 & mast cell protease 8 & $+3,46$ \\
\hline Mcpt1l1 & mast cell protease 1 -like 1 & $+3,44$ \\
\hline Mcpt8l2 & mast cell protease 8 -like 2 & $+3,30$ \\
\hline Ccrlo & $\mathrm{C}-\mathrm{C}$ motif chemokine receptor 10 & $+3,12$ \\
\hline Cxcllo & $\mathrm{C}-\mathrm{X}-\mathrm{C}$ motif chemokine ligand 10 & $+2,96$ \\
\hline$E d a$ & ectodysplasin-A & $+2,94$ \\
\hline$H r h 2$ & histamine receptor $\mathrm{H} 2$ & $+2,77$ \\
\hline Cxcll3 & $\mathrm{C}-\mathrm{X}-\mathrm{C}$ motif chemokine ligand 13 & $+2,76$ \\
\hline Cxcll & $\mathrm{C}-\mathrm{X}-\mathrm{C}$ motif chemokine ligand 1 & $+2,48$ \\
\hline$A h r$ & aryl hydrocarbon receptor & $+2,46$ \\
\hline Mcpt2 & mast cell protease 2 & $+2,25$ \\
\hline Mcpt1l3 & mast cell protease 1 -like 3 & $+2,22$ \\
\hline Vpreb3 & V-set pre-B cell surrogate light chain 3 & $+2,14$ \\
\hline Ccr6 & C-C motif chemokine receptor 6 & $+2,06$ \\
\hline Fcmr & Fc fragment of $\operatorname{IgM}$ receptor & $+2,05$ \\
\hline Ccl4 & C-C motif chemokine ligand 4 & $-6,65$ \\
\hline Olrl & oxidized low density lipoprotein receptor 1 & $-5,25$ \\
\hline$C d 40$ & CD40 molecule & $-4,82$ \\
\hline Kcnn4 & potassium calcium-activated channel subfamily $\mathrm{N}$ member 4 & $-4,68$ \\
\hline $\operatorname{Prg} 4$ & proteoglycan 4 & $-3,37$ \\
\hline$C d 36$ & CD36 molecule & $-3,32$ \\
\hline Inpp5d & inositol polyphosphate-5-phosphatase D & $-2,66$ \\
\hline$R T 1-B b$ & RT1 class II, locus Bb & $-2,54$ \\
\hline Enpp3 & ectonucleotide pyrophosphatase/phosphodiesterase 3 & $-2,52$ \\
\hline Tnfaipl & TNF alpha induced protein 1 & $-2,48$ \\
\hline $\operatorname{Tnf}$ & tumor necrosis factor & $-2,36$ \\
\hline Map3k14 & mitogen-activated protein kinase kinase kinase 14 & $-2,34$ \\
\hline Cd300lf & Cd300 molecule-like family member F & $-2,24$ \\
\hline Ccrl & C-C motif chemokine receptor 1 & $-2,22$ \\
\hline$R T 1 C E 12$ & RT1 class I, locus CE12 & $-2,18$ \\
\hline$F c g r 2 b$ & Fc fragment of IgG receptor IIb & $-2,17$ \\
\hline$R T 1-C l$ & $\mathrm{RT} 1$ class $\mathrm{Ib}$, locus $\mathrm{Cl}$ & $-2,08$ \\
\hline Vavl & vav guanine nucleotide exchange factor 1 & $-2,03$ \\
\hline
\end{tabular}




\begin{tabular}{llr}
\hline$C d 244$ & CD244 molecule & $-2,02$ \\
$C d 274$ & CD274 molecule & $-2,02$ \\
\hline
\end{tabular}

Fonte: GeneSpring 14.9 GX/DAVID (Database for Annotation, Visualization and Integrated Discovery).

Adicionalmente, o diabetes induziu a expressão do gene Pparg (peroxisome proliferator-activated receptor gamma), relacionado com a diferenciação adipogênica das CTMs (Tabela 12).

Tabela 12 - CTMs dos ratos diabéticos vs CTMs dos ratos saudáveis: Expressão do gene Pparg.

\begin{tabular}{llc}
\hline Genes & Descrição & Fold-Change \\
\hline Pparg & peroxisome proliferator-activated receptor gamma & $+2,22$ \\
\hline
\end{tabular}

Fonte: GeneSpring 14.9 GX/DAVID (Database for Annotation, Visualization and Integrated Discovery).

O diabetes, no entanto, não influenciou de forma notória a expressão de genes relacionados com os processos de regulação positiva da biossíntese de colágeno, resposta inflamatória, quimiotaxia celular e metabolismo de glicose (Tabelas 13 a 16).

Tabela 13 - CTMs dos ratos diabéticos vs CTMs dos ratos saudáveis: Genes diferencialmente expressos relacionados com a regulação positiva da biossíntese de colágeno.

\begin{tabular}{llr}
\hline Genes & Descrição & Fold-Change \\
\hline$I h h$ & Indian hedgehog & $+2,29$ \\
$B m p 4$ & bone morphogenetic protein 4 & $+2,28$ \\
$M k x$ & mohawk homeobox & $+2,24$ \\
$R g c c$ & regulator of cell cycle & $-2,42$ \\
$T g f b 1$ & transforming growth factor, beta 1 & $-2,10$ \\
$T g f b 3$ & transforming growth factor, beta 3 & $-2,03$ \\
\hline
\end{tabular}

Fonte: GeneSpring 14.9 GX/DAVID (Database for Annotation, Visualization and Integrated Discovery).

Tabela 14 - CTMs dos ratos diabéticos vs CTMs dos ratos saudáveis: Genes diferencialmente expressos relacionados com a regulação positiva da resposta inflamatória.

\begin{tabular}{llc}
\hline Genes & Descrição & Fold-Change \\
\hline Il6 & interleukin 6 & $+3,34$ \\
Tacl & tachykinin, precursor 1 & $+2,41$ \\
Klk1 & kallikrein 1 & $+2,03$ \\
Adam8 & ADAM metallopeptidase domain 8 & $-3,15$ \\
\hline
\end{tabular}




\begin{tabular}{lc}
\hline Alox5ap arachidonate 5-lipoxygenase activating protein & $-2,02$ \\
\hline Fonte: GeneSpring 14.9 GX/DAVID (Database for Annotation, Visualization and Integrated Discovery).
\end{tabular}

Tabela 15 - CTMs dos ratos diabéticos vs CTMs dos ratos saudáveis: Genes diferencialmente expressos relacionados com o processo de regulação positiva da quimiotaxia celular.

\begin{tabular}{llc}
\hline Genes & Descrição & Fold-Change \\
\hline Angptl & angiopoietin 1 & $+3,14$ \\
Vegfc & vascular endothelial growth factor C & $+2,34$ \\
Bmp4 & bone morphogenetic protein 4 & $+2,28$ \\
Fgf8 & fibroblast growth factor 8 & $-3,26$ \\
Corola & coronin 1A & $-2,98$ \\
Ccl3 & C-C motif chemokine ligand 3 & $-2,37$ \\
\hline
\end{tabular}

Fonte: GeneSpring 14.9 GX/DAVID (Database for Annotation, Visualization and Integrated Discovery).

Tabela 16- CTMs dos ratos diabéticos vs CTMs dos ratos saudáveis: Genes diferencialmente expressos relacionados com o metabolismo de glicose.

\begin{tabular}{llr}
\hline Genes & Descrição & Fold-Change \\
\hline Igf2 & insulin-like growth factor 2 & $+5,25$ \\
Pdha2 & pyruvate dehydrogenase alpha 2 & $+3,58$ \\
Apod & apolipoprotein D & $+2,90$ \\
Pik3ca & phosphatidylinositol-4,5-bisphosphate 3-kinase, catalytic subunit alpha & $+2,07$ \\
Gckr & glucokinase regulator & $-2,76$ \\
Pgm1 & phosphoglucomutase 1 & $-2,75$ \\
Pkm & pyruvate kinase, muscle & $-2,29$ \\
Usf1 & upstream transcription factor 1 & $-2,16$ \\
$P d h b$ & pyruvate dehydrogenase (lipoamide) beta & $-2,08$ \\
\hline
\end{tabular}

Fonte: GeneSpring 14.9 GX/DAVID (Database for Annotation, Visualization and Integrated Discovery).

\subsection{Confirmação dos dados do microarray por PCR em tempo real}

Os dados do microarray foram confirmados pelos resultados do PCR em tempo real para os genes analisados (Bmp4, Spp1, Kdr e Pecam1). Pelo microarray, as CTMs dos ratos diabéticos apresentaram, em relação às CTMs dos ratos saudáveis, uma sobre-expressão dos genes Bmp4, Kdr e Pecaml e uma expressão reprimida do gene Sppl. Esses dados estão de acordo com os resultados do PCR em tempo real, conforme mostra a Figura 6. 


\section{Bmp4}

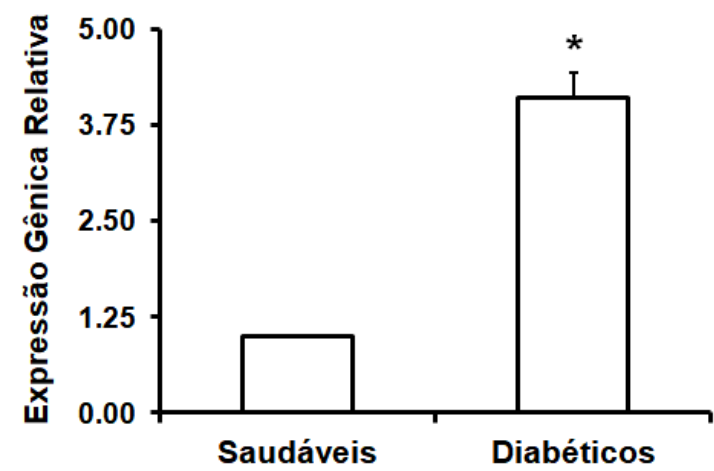

$\mathrm{Kdr}$

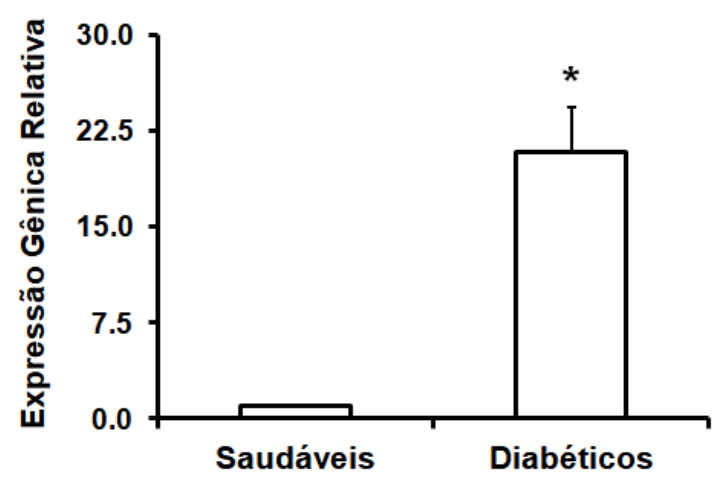

Spp1

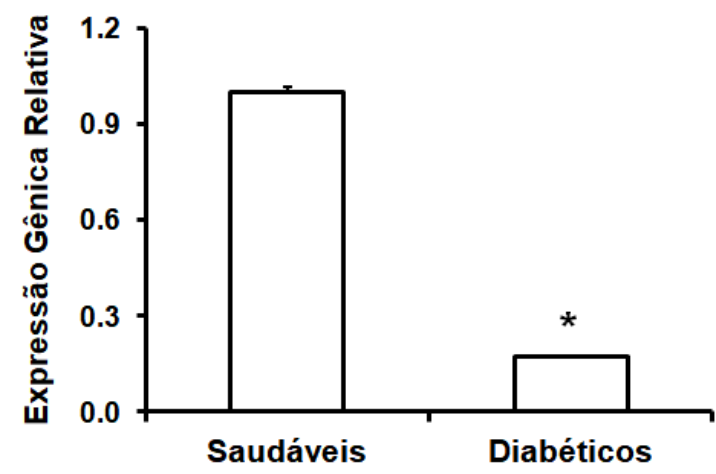

Pecam1

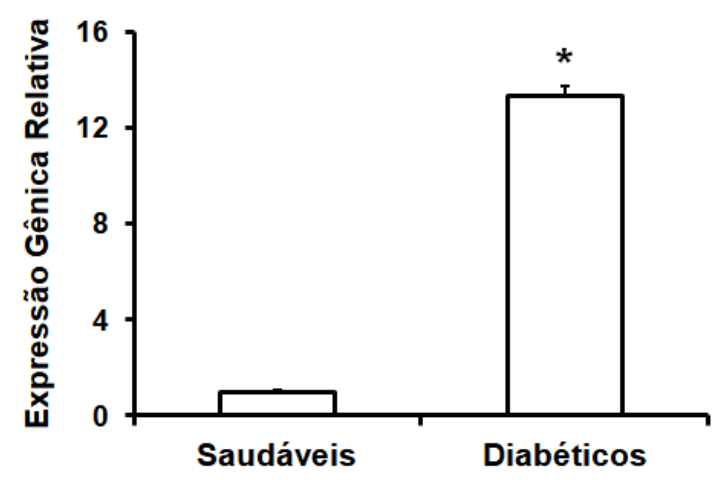

Figura 6 - Expressão relativa dos genes Bmp4, Sppl, Kdr e Pecaml por PCR em tempo real (Student's T Test, * $\mathrm{p} \leq 0.001)$.

\section{Discussão}

Considerando o efeito da hiperglicemia sobre o metabolismo do tecido ósseo e o papel que as CTMs desempenham no processo de osteogênese, nós investigamos, através da análise da expressão gênica em larga escala, a influência do diabetes mellitus sobre as características moleculares de CTMs derivadas da medula óssea de ratos.

A análise do dendrograma mostra o agrupamento hierárquico das CTMs no mesmo cluster, no entanto, aponta diferenças entre os perfis de expressão gênica das CTMs derivadas dos ratos diabéticos e dos ratos saudáveis. Essas diferenças podem ser detalhadas pela análise da caracterização funcional dos genes diferencialmente expressos, que relaciona o grupo de genes envolvidos com cada processo biológico. Nesse sentido, os resultados mostraram que todos os processos biológicos considerados no estudo foram enriquecidos 
tanto por genes induzidos como por genes reprimidos. No entanto, as análises da modulação da expressão de cada gene apontaram diferenças relevantes entre as CTMs provenientes dos ratos diabéticos e dos ratos saudáveis.

No tocante ao processo de diferenciação osteoblástica, as CTMs derivadas dos ratos diabéticos apresentaram, em relação às CTMs dos ratos saudáveis, uma sobre-expressão de genes como o Igf2 (insulin-like growth factor 2), Bmp4 (bone morphogenetic protein 4) e Bmp8a (bone morphogenetic protein 8a) e uma expressão reprimida de genes como o Sppl (secreted phosphoprotein 1), Lefl (lymphoid enhancer binding factor 1), Ibsp (integrinbinding sialoprotein) e Bmp7 (bone morphogenetic protein7), entre outros. No entanto, a repressão dos genes envolvidos com esse processo foi mais acentuada que a indução, o que sugere que o diabetes pode ter um efeito inibitório sobre o potencial de diferenciação osteoblástica das CTMs. Dentre os genes relacionados com a diferenciação osteoblástica, o gene Sppl foi o mais modulado, apresentando um fold-change negativo de 8,07. A fosfoproteína secretada, também chamada de osteopontina, codificada pelo gene Sppl, é uma das proteínas não colágenas mais abundantes presente na matriz óssea. Essa proteína é secretada por osteoblastos e apresenta alta afinidade pelo íon cálcio e pela hidroxiapatita, tendo um papel fundamental na iniciação da mineralização da matriz extracelular (Bianco et al., 1991; Gordon et al., 2007; Malaval et al., 2009; Bouleftour et al., 2015). A expressão reprimida desse gene mostra que o diabetes mellitus pode exercer uma influência negativa sobre aspectos importantes do metabolismo ósseo, como a atividade dos osteoblastos e a mineralização da matriz extracelular. Em contrapartida, as células dos ratos diabéticos apresentaram, em relação às saudáveis, uma sobre-expressão do gene Pparg (peroxisome proliferator-activated receptor gamma, fold-change positivo de 2,22), que é considerado um regulador chave diferenciação adipogênica (Stechschulte et al., 2016). A sobre-expressão do gene Pparg induz a diferenciação adipogênica das CTMs em detrimento da diferenciação osteoblástica (Lecka-Czernik et al., 1999), o que reduz a formação óssea e compromete a qualidade do tecido. Os perfis de expressão gênica apresentados pelos genes Sppl (repressão) e Pparg (indução), no presente estudo, estão de acordo com os resultados de estudos in vitro que avaliaram, por PCR em tempo real, o efeito da hiperglicemia sobre a expressão de marcadores osteogênicos e adipogênicos em CTMs (Tolosa et al., 2013; Silva et al., 2015; Cao et al., 2016; Peng et al., 2016).

Com relação ao processo de regulação positiva da mineralização óssea, as células provenientes dos ratos diabéticos apresentaram, em relação às células saudáveis, uma sobre- 
expressão dos genes Gpm6b (glycoprotein m6b) e Bmp4 (bone morphogenetic protein 4) e uma expressão reprimida de vários genes, entre eles Fam20c (golgi associated secretory pathway kinase), Acvr2b (activin A receptor type 2B) e Fbn2 (fibrillin 2). Entre os genes mais modulados estão o Gpm6b, com fold-change positivo de 2,51 e o Fam20c, com fold-change negativo de 2,34. A glicoproteína m6b, codificada pelo gene Gpm6b, é uma proteína de membrana relacionada coma diferenciação osteoblástica e com a mineralização da matriz (Drabek et al., 2011). O gene Fam20c traduz uma proteína pertencente à família das kinases que se liga ao íon cálcio e atua na fosforilação de proteínas envolvidas no processo de mineralização óssea (Liu et al., 2018). Porém, da mesma forma que o observado para o processo de diferenciação osteoblástica, a repressão de genes envolvidos com a regulação positiva da mineralização óssea foi mais acentuada que a indução, o que reforça o efeito negativo do diabetes sobre a mineralização da matriz extracelular. Adicionalmente, o diabetes também parece ter uma influência desfavorável sobre o processo relacionado com a regulação positiva do transporte do íon cálcio. Esses resultados, em conjunto, corroboram com os obtidos em diversos estudos in vitro e in vivo, realizados com CTMs derivadas da medula óssea, que relatam que o diabetes inibiu a expressão de marcadores osteogênicos e o potencial de diferenciação osteoblástica das CTMs comprometendo, dessa forma, a atividade dos osteoblastos e a formação de matriz mineralizada ( $\mathrm{Lu}$ et al., 2003; Wang et al., 2010; Juncheng et al., 2013; Tolosa et al., 2013; Zhao et al., 2013; Weinberg et al., 2014; Qian et al., 2015; Peng et al., 2016; Filion et al., 2017).

Por outro lado, com relação à regulação negativa da diferenciação osteoclástica, os resultados mostraram que o diabetes induziu a expressão de Sfrpl(secreted frizzled-related protein 1) e reprimiu a expressão dos genes $F$ stl3 (follistatin like 3), Inpp5d (inositol polyphosphate-5-phosphatase D), Ccl3 (C-C motif chemokine ligand 3) e Lilrb4 (leukocyte immunoglobulin like receptor B4). Esses dados sugerem que o diabetes pode induzir a diferenciação osteoclástica, o que favoreceria a reabsorção do tecido ósseo, no entanto, não há um consenso estabelecido na literatura acerca do impacto do diabetes sobre a atividade osteoclástica (Palermo et al., 2017). Segundo Cunha e colaboradores (2014) a fragilidade óssea associada ao diabetes não está relacionada com a atividade osteoclástica ou com a reabsorção óssea, mas sim, com as alterações que ocorrem no processo de mineralização da matriz extracelular.

O diabetes também influenciou de forma negativa a expressão de genes relacionados com os processos de ossificação, regeneração e coagulação sanguínea, sendo que 
esse efeito foi mais acentuado no processo de regeneração, ou seja, as CTMs dos ratos diabéticos apresentaram uma maior repressão de genes envolvidos com a cicatrização e regeneração tecidual. Por outro lado, os resultados mostraram uma tendência do diabetes em favorecer os processos de angiogênese e de resposta imune, pelo menos dentro do período experimental considerado no estudo. Adicionalmente, outros processos como a regulação positiva da biossíntese de colágeno, regulação positiva da resposta inflamatória aguda, quimiotaxia celular e metabolismo de glicose não foram influenciados de forma notória pelo diabetes, o que pode estar relacionado com o curto período compreendido entre a confirmação do diabetes, avaliado pelos níveis de glicose sanguínea dos animais, e a coleta das células. $\mathrm{O}$ diabetes é considerado uma doença crônica e magnitude das alterações provocadas pela hiperglicemia sobre os tecidos se agrava ao longo do tempo (Stolzing et al., 2010).

Com relação ao potencial angiogênico, as CTMs derivadas dos ratos diabéticos apresentaram, em relação às saudáveis, uma sobre-expressão de genes considerados relevantes para o processo de formação vascular, como o $K d r$ (kinase insert domain receptor), Esml (endothelial cell-specific molecule 1), o Pecaml (platelet and endothelial cell adhesion molecule 1), a Angptl4 (angiopoietin-like 4) e o Vegfc (vascular endothelial growth factor C). O $K d r$, também chamado de Vegfr2, é considerado o principal mediador entre a célula endotelial e o $\operatorname{Vegf}$ (vascular endothelial growth factor). A ativação desse receptor estimula a proliferação, migração e diferenciação da célula endotelial (Bao et al., 2009). A proteína codificada pelo gene Pecaml é uma molécula de adesão presente nas células endoteliais, plaquetas e células de defesa. O gene Angptl4 traduz uma proteína que atua como um hormônio regulando a homeostasia de glicose, o metabolismo de lipídeos e a sensibilidade da célula à insulina, além de exercer um efeito anti-apoptótico, favorecendo a manutenção das células endoteliais (Morris, 2018). Apesar deste estudo apresentar resultados positivos em termos de expressão de genes considerados fundamentais para o processo de angiogênese, diversos estudos in vitro (Kim et al., 2013, Kim et al., 2014; Rezabakhsh et al., 2017) e in vivo (Schumann et al, 2015) relatam que a hiperglicemia inibe o potencial angiogênico das CTMs. Análises do genoma de CTMs isoladas da medula óssea de camundongos diabéticos, realizadas por microarray, concluíram que o diabetes pode comprometer o processo de angiogênese (Yang et al., 2016).

No presente estudo, as CTMs dos ratos diabéticos apresentaram ainda, em relação às células saudáveis, uma sobre-expressão dos genes $\mathrm{Cxcl}$ ( $\mathrm{C}-\mathrm{X}-\mathrm{C}$ motif chemokine ligand 1) e $I l 6$ (interleukin 6) relacionados, respectivamente, com o processo imune e com a resposta 
inflamatória e uma expressão reprimida do gene $T g f b 1$ (transforming growth factor, beta 1), que participa da biossíntese de colágeno e do gene Procr (protein $\mathrm{C}$ receptor) envolvido no processo de coagulação sanguínea. No caso da coagulação sanguínea, um importante gene foi sobre-expresso, o $v W F$ (von willebrand factor), que atua favorecendo a adesão e a aglutinação plaquetária (Bao et al., 2009). Estes resultados concordam com os obtidos por Morris e colaboradores (2018), que obtiveram uma sobre-expressão dos genes Cxcll e Il6 quando avaliaram, por microarray, o genoma de CTMs obtidas da medula óssea de pacientes diabéticos. Os perfis de expressão dos genes Angptl4, Tgfbl e Procr, observadas no presente estudo, corroboram com os resultados do estudo de Kim e colaboradores (2014), que realizaram uma análise genômica de CTMs da medula óssea de ratos diabéticos, por microarray, e obtiveram uma sobre-expressão do gene Angptl4 e uma expressão reprimida dos genes Tgfbl e Procr.

De forma geral, esses dados mostram que o diabetes mellitus influenciou as características moleculares das CTMs, alterando a expressão de genes envolvidos com processos biológicos considerados relevantes para a formação e regeneração óssea. No entanto, é importante considerar que a magnitude do efeito do diabetes mellitus sobre a expressão gênica das células pode sofrer influência de alguns fatores, como os níveis de glicemia sanguínea e o estágio evolutivo da doença (Stolzing et al., 2010).

\section{Conclusões}

Pelos dados do microarray, é possível concluir que o diabetes mellitus alterou as características moleculares das CTMs, influenciando a expressão de genes envolvidos com processos biológicos considerados relevantes para a formação e regeneração óssea. 


\section{Referências*}

Abuna R. P., de Oliveira F. S., De S. Santos T., Guerra T. R., Rosa A. L., Beloti M. M. Participation of TNF- $\alpha$ in inhibitory effects of adipocytes on osteoblast differentiation. J Cell Physiol, v. 231, p. 204-214, 2016.

Akbarzadeh A., Norouzian D., Mehrabi M. R., Jamshidi S., Farhangi A., Allah Verdi A., Mofidian S. M. A., Lame Rad B. Induction of diabetes by streptozotocin in rats. Indian J Clin Biochem, v. 22 (2), p. 60-64, 2007.

Bao P., Kodra A., Tomic-Canic M., Golinko M. S., Ehrlich H. P., Brem H. The role of vascular endothelial growth factor in wound healing. J Surg Res, v. 153, p. 347-358, 2009.

Baynes, J. W. Role of Oxidative Stress in Development of Complications in Diabetes. Diabetes, v. 40, p. 405-412, 1991.

Bianco P., Fisher L. W., Young M. F., Termine J. D., Robey P. G. Expression of bone sialoprotein (BSP) in developing human tissues. Calcif Tissue Int, v. 49 (6), p. 421-426, 1991.

Bouleftour W., Juignet L., Bouet G., Granito R. N., Vanden-Bossche A., Laroche N., Aubin J. E., Lafage-Proust M., Vico L., Malaval L. The role of the SIBLING, Bone Sialoprotein in skeletal biology - Contribution of mouse experimental genetics. Matrix Biol, v. 52, p. 60-77, 2015.

Brennan M. A., Renaud A., Guilloton F., Mebarki M., Trichet V., Sensebé L., Deschaseaux F., Chevallier N., Layrolle P. Inferior in vivo osteogenesis and superior angiogeneis of human adipose tissue: a comparison with bone marrow-derived stromal stem cells cultured in xenofree conditions. Stem Cells Transl Med, v. 6, p. 2160-2172, 2017.

Cao B., Lui N., Wang W. High glucose prevents osteogenic differentiation of mesenchymal stem cells via lncRNA AK028326/CXCL13 pathway. Biomedicine \& Pharmacotherapy, v. 84, p. 544-551, 2016.

Cruz N.G., Sousa L.P., Sousa M.O., Pietrani N.T., Fernandes A.P., Gomes K.B. The linkage between inflammation and type 2 diabetes mellitus. Diabetes Res Clin Pract, v. 99(2), p. 8592, 2013.

Cunha J. S., Ferreira V. M., Maquigussa E., Naves M. A., Boim M. A. Effects of high glucose and high insulin concentrations on osteoblast function in vitro. Cell Tissue Res, v. 358, p. 249-256, 2014.

Delgado-Calle J., Sato A.Y., Bellido T. Role and mechanism of action of sclerostin in bone. Bone, v. 96, p. 29-37, 2007.

Deng X., Xu M., Shen M., Cheng J. Effects of Type 2 Diabetic Serum on Proliferation and Osteogenic Differentiation of Mesenchymal Stem Cells. J Diabetes Res, v. 2018, p. 1-9, 2018.

Drabek K., Van de Peppel J., Eijken M., Van Leeuwen J. P. T. M. GPM6B Regulates Osteoblast Function and Induction of Mineralization by Controlling Cytoskeleton and Matrix Vesicle Release. J Bone Miner Res, v. 26 (9), p. 2045-2051, 2011. 
Ehnert S., Freude T., Ihle C. et AL. Factors circulating in the blood of type 2 diabetes mellitus patients affect osteoblast maturation - description of a novel in vitro model. Exp Cell Res, v. 332, p.247-258, 2015.

Fadini G. P., Albiero M., Kreutzenberg S.V., Boscaro E., Cappellari R., Marescotti M. C. et al. Diabetes Impairs Stem Cell and Proangiogenic CellMobilization in Humans. Diabetes Care, v. 36, p. 943-949, 2013.

Filion T. M., Skelly J. D., Huang H., Greiner D. L., Ayers D. C., Song J. Impaired osteogenesis of T1DM bone marrow-derived stromal cells and periosteum-derived cells and their differential in-vitro responses to growth factor rescue. Stem Cell Research \& Therapy, v.8, p. 65-75, 2017.

Freitas G., Lopes H., Almeida A. L. G., Abuna R., Gimenes R., Souza L. E. B. et al. Potential of Osteoblastic Cells Derived from Bone Marrow and Adipose Tissue Associated with a Polymer/Ceramic Composite to Repair Bone Tissue. Calcif Tissue Int, v. 101, p. 312-320, 2017.

Garcia-Hernandez A., Arzate H., Gil-Chavarria I., Rojo R., Moreno-Fierros L. High glucose concentrations alter the biomineralization process in human osteoblastic cells. Bone, v. 50(1), p. 276-88, 2012.

Gaudio A., Privitera F., Battaglia K., Torrisi V., Sidoti M.H., Pulvirenti I., et al. Sclerostin levels associated with inhibition of the Wnt/beta-catenin signaling and reduced bone turnover in type 2 diabetes mellitus. J Clin Endocrinol Metab, v. 97, p. 3744-50, 2012.

Gennari L., Merlotti D., Valenti R., Ceccarelli E., Ruvio M., Pietrini M.G., et al. Circulating sclerostin levels and bone turnover in type 1 and type 2 diabetes. J Clin Endocrinol Metab, v. 97, p. 1737-44. 2012.

Gordon J. A. R., Tye C. E., Sampaio A. V., Underhill T. M., Hunter G. K., Goldberg H. A. Bone sialoprotein expression enhances osteoblast differentiation and matrix mineralization in vitro. Bone, v. 41, p. 462-473, 2007.

Graves D.T., Kayal R.A. Diabetic complications and dysregulated innate immunity. Front Biosci, v.13, p. 1227-39, 2008.

Hamann C., Goettsch C., Mettelsiefen J., Henkenjohann V., Rauner M., Hempel U., Bernhardt R., Fratzl-Zelman N., Roschger P., Rammelt S., Günther K. P., Hofbauer L. C. Delayed bone regeneration and low bone mass in a rat model of insulin-resistant type 2 diabetes mellitus is due to impaired osteoblast function. Am J Physiol Endocrinol Metab, v. 301, p. 1220-1228, 2011.

IDF Diabetes Atlas. International Diabetes Federation, $8^{\text {th }}$ ed., 2017. Disponível em: $<$ www.diabetesatlas.org>

Jiao H., Xiao E., Graves D. T. Diabetes and Its Effect on Bone and Fracture Healing. Curr Osteoporos Rep, v. 13, p. 327-335, 2015.

Jin P., Zhang X., Wu L., Li L., Yin Q., Zheng L., Zhang H., Sun C. Streptozotocin-Induced Diabetic Rat-Derived Bone Marrow Mesenchymal Stem Cells Have Impaired Abilities in 
Proliferation, Paracrine, Antiapoptosis, and Myogenic Differentiation. Transplantation Proceedings, v. 42, p. 2745-2752, 2010.

Juncheng W., Bin W., Ying Li, Dongsheng W., Lingling E., Yang B., Hongchen Li. High glucose inhibits osteogenic differentiation through the BMP signaling pathway in bone mesenchymal stem cells in mice. EXCLI J, v. 12, p. 584-597, 2013.

Kachgal S. \& Putnam A. J. Mesenchymal stem cells from adipose and bone marrow promote angiogenesis via distinct cytokine and protease expression mechanisms. Angiogenesis, v. 14 (1), p. 47-59, 2011.

Kanazawa I. Interaction between bone and glucose metabolism. Endocr J, v. 64 (11), p. $1043-$ 1053, 2017.

Kasperk C., Georgescu C., Nawroth P. Diabetes Mellitus and Bone Metabolism. Exp Clin Endocrinol Diabetes, v. 125 (4), p. 213-217, 2017.

Kim Y. S., Kwon J. S., Hong M. H., Kang W. S., Jeong H., Kang H. et al. Restoration of angiogenic capacity of diabetes-insulted mesenchymal stem cells by oxytocin. BMC Cell Biology, v.14, p. 38-49, 2013.

Kim Y. S., Kang H. J., Hong M. H., Kang W. S., Choe N., Kook H. et al. Angiopoietin-Like 4 Is Involved in the Poor Angiogenic Potential of High Glucose-Insulted Bone Marrow Stem Cells. Korean Circ J, v. 44 (3), p. 177-183, 2014.

Ko K. I., Coimbra L. S., Tian C., Alblowi J., Kayal R. A., Einhorn T. A., et al. Diabetes reduces mesenchymal stem cells in fracture healing through a TNF $\alpha$-mediated mechanism. Diabetologia, v. 58(3), p. 633-642, 2015.

Krampera M., Galipeau J., Shi Y.,Tarte K., Sensebe L. Immunological characterization of multipotent mesenchymal stromal cells. Cytotherapy, v. 15, p. 1054-1061, 2013.

Lecka-Czernik B., Gubrij I., Moerman E.J., et al. Inhibition of Osf2/Cbfa1 expression and terminal osteoblast differentiation by PPARgamma2. J Cell Biochem, v. 74(3), p. 357-71, 1999.

Lecka-Czernik B. Diabetes, bone and glucose-lowering agents: basic biology. Diabetologia, v. 60, p. 1163-1169, 2017.

Li J., Liu C. Y., Jiang Y. F., Wei X. Z., Li J. U. Proliferation and differentiation of human osteoblasts from a type 2 diabetic patient in vitro. Genet Mol Res, v. 14 (3), p. 11292-11299, 2015 .

Liu C., Zhang H., Jani P., Wang X., Lu Y., Li N., Xiao J., Qin C. FAM20C regulates osteoblast behaviors and intracellular signaling pathways in a cell-autonomous manner. $\mathrm{J}$ Cell Physiol, v. 233, p. 3476-3486, 2018.

Livak K. J., Schmittgen T. D. Analysis of relative gene expression data using real-time quantitative PCR and the 2(-Delta Delta C(T)) Method. Methods, v. 25 (4), p. 402-408, 2001. 
Lu H., Kraut D., Gerstenfeld L. C., Graves D. Diabetes Interferes with the Bone Formation by Affecting the Expression of Transcription Factors that Regulate Osteoblast Differentiation. Endocrinol, v. 144 (1), p. 346-352, 2003.

Lui C., Jiang D. High glucose-induced LIF suppresses osteoblast differentiation via regulating STAT3/SOCS3 signaling. Cytokine, v. 91, p. 132-139, 2017.

Malaval L., Monfoulet L., Fabre T., Pothuaud L., Bareille R., Miraux S., Thiaudiere E., Raffard G., Franconi J., Lafage-Proust M., Aubin J. E., Vico L., Joëlle Amédée J. Absence of bone sialoprotein (BSP) impairs cortical defect repair in mouse long bone. Bone, v. 45 (5), p. 853-861, 2009.

Manavalan J.S., Cremers S., Dempster D.W. et al. Circulating osteogenic precursor cells in type 2 diabetes mellitus. J Clin Endocrinol Metab, v. 97, p. 3240-3250, 2012.

Mangialardi G., Spinetti G., Reni C., Madeddu P. Reactive Oxygen Species Adversely Impacts Bone Marrow Microenvironment in Diabetes. Antioxid Redox Signal, v. 21 (11), p. 1620-1633, 2014.

Mangialardi G., Madeddu P. Bone Marrow-Derived Stem Cells: a Mixed Blessing in the Multifaceted World of Diabetic Complications. Curr Diab Rep, v. 16, p. 43-55, 2016.

Manieri N. A., Mack M. R., Himmelrich M. D., Worthley D. L., Hanson E. M., Eckmann L., Wang T. C., Stappenbeck T. S. Mucosally transplanted mesenchymal stem cells stimulate intestinal healing by promoting angiogenesis. J Clin Invest, v. 125 (9), p. 3606-3618, 2015.

Meier C., Schwartz A. V., Egger A., Lecka-Czernik B. Effects of diabetes drugs on the skeleton. Bone, v. 82, p. 93-100, 2016.

Montespan F., Deschaseaux F., Sensébé L., Carosella E. D., Rouas-Freiss N. Osteodifferentiated Mesenchymal Stem Cells from Bone Marrow and Adipose Tissue Express HLA-G and Display Immunomodulatory Properties in HLA-Mismatched Settings: Implications in Bone Repair Therapy. J Immunol Res, v. 2014, p. 1-10, 2014.

Morris A. Obesity: ANGPTL4 - the link binding obesity and glucose intolerance. Nat Ver Endocrinol, v. 14 (5), p. 251. 2018.

Morris A. D., Dalal S., Li H., Brewster L. P. Human diabetic mesenchymal stem cells from peripheral arterial disease patients promote angiogenesis through unique secretome signatures. Surgery, v. 163, p.870-876, 2018.

Moseley K.F. Type 2 diabetes and bone fractures. Curr Opin Endocrinol Diabetes Obes, v. 19(2), p. 128-35, 2012.

Niemeyer P., Fechner K., Milz S., Richter W., Suedkamp N. P., Mehlhorn A. T., Pearce S., Kasten P. Comparison of mesenchymal stem cells from bone marrow and adipose tissue for bone regeneration in a critical size defect of the sheep tíbia and the influence of platelet-rich plasma. Biomaterials, v. 31, p. 3572-3579, 2010.

Ogawa N., Yamaguchi T., Yano S., Yamauchi M., Yamamoto M., Sugimoto T. The combination of high glucose and advanced glycation end-products (AGEs) inhibits the 
mineralization of osteoblastic MC3T3-E1 cells through glucose-induced increase in the receptor for AGEs. Horm Metab Res, v. 39(12), p. 871-5, 2007.

Okazaki K., Yamaguchi T., Tanaka K., Notsu M., Ogawa N., et al. Advanced glycation end products (AGEs), but not high glucose, inhibit the osteoblastic differentiation of mouse stromal ST2 cells through the suppression of osterix expression, and inhibit cell growth and increasing cell apoptosis. Calcif Tissue Int, v. 91, p. 286-296, 2012.

Oryan A., Papaioannou N., Kamali A., Stylianaki I., Mesenchymal Stem Cells and Immunomodulation: Implications in Bone Tissue Engineering. Int Clin Pathol J, v. 2, p. 1-3, 2016.

Owen M. \& Friedenstein A. J. Stromal stem cells: marrow derived osteogenic precursors. Novartis Found Symp (136), p. 42-60, 1988.

Palermo A., D’Onofrio L., Buzzetti R., Manfrini S., Napoli N. Pathophysiology of Bone Fragility in Patients with Diabetes. Calcif Tissue Int, v. 100, p. 122-132, 2017.

Peng L., Jia Z., Yin X., Zhang X., Liu Y, Chen P., Ma K, Zhou C. Comparative analysis of mesenchymal stem cells from bone marrow, cartilage, and adipose tissue. Stem Cells Dev, v. 17, p. 761-773, 2008.

Peng J., Hui K., Hao C., Peng Z., Gao Q. X., Jin Q., et al. Low bone turnover and reduced angiogenesis in streptozotocin-induced osteoporotic mice. Connect Tissue Res, v. 57 (4), p. 277-289, 2016.

Picke A. K., Alaguero I. G., Campbell G. M.,Glüer C. C., Salbach-Hirsch J., Rauner M., Hofbauer L. C., Hofbauer C. Bone defect regeneration and cortical bone parameters of type 2 diabetic rats are improved by insulin therapy. Bone, v. 82, p. 108-115, 2016.

Pittenger M. F., Mackay A. M., Beck S. C., Jaiswal R. K. et al. Multilineage potencial of adult human mesenchymal stem cells. Science, v. 284 (2), p. 143-147, 1999.

Prockop D. J. Marrow stromal cells as stem cells for nonhematopoietic tissues. Science, v. 276, p. 71-74, 1997.

Qian C., Zhu C., Yu W., Jiang X., Zhang F. High-Fat Diet/Low-Dose Streptozotocin-Induced Type 2 Diabetes in Rats Impacts Osteogenesis and Wnt Signaling in Bone Marrow Stromal Cells. PLoS ONE, v. 10(8), 2015.

Rezabakhsh A., Cheraghi O., Nourazarian A., Hassanpour M., Kazemi M., Ghaderi S., et al. Type 2 Diabetes Inhibited Human Mesenchymal Stem Cells Angiogenic Response by OverActivity of the Autophagic Pathway. Journal of Cellular Biochemistry, v. 118, p. 1518-1530, 2017.

Saito M., Fujii K., Mori Y., Marumo K. Role of collagen enzymatic and glycation induced cross-links as a determinant of bone quality in spontaneously diabetic WBN/Kob rats. Osteoporos Int, v. 17, p. 1514-23, 2006.

Saito M., Marumo K. Bone quality in diabetes. Front Endocrinol (Lausanne), v. 4, p.72, 2013. 
Sakaguchi Y., Sekiya I., Yagishita K., Muneta T. Comparison of human stem cells derived from various mesenchymal tissues. Arthritis Rheum, v. 52, p. 2521-2529, 2005.

Santana R. B., Xu L., Chase H. B., Amar S.,Graves D. T., Trackman P. C. A Role for Advanced Glycation End Products in Diminished Bone Healing in Type 1 Diabetes. Diabetes, v. 52, p. 1502-1510, 2003.

Schumann P., Lindhorst D., Kampmann A., Gellrich N. C., Krone-Wolf S., MeyerLindenberg A., et al. Decelerated vascularization in tissue-engineered constructs in association with diabetes mellitus in vivo. Journal of Diabetes and Its Complications, v. 29, p. 855-864, 2015.

Schwartz A.V., Garnero P., Hillier T.A., Sellmeyer D.E., Strotmeyer E.S., Feingold K.R., et al. Pentosidine and increased fracture risk in older adults with type 2 diabetes. J Clin Endocrinol Metab, v. 94, p. 2380-6, 2009.

Silva J. C., Sampaio P., Fernandes M. H., Gomes P. S. The Osteogenic Priming of Mesenchymal Stem Cells is Impaired in Experimental Diabetes. J Cell Biochem, v. 116, p. 1658-1667, 2015.

Smadja D. M., C d'Audigier C., Guerin C. L., Mauge L., Dizier B., J-S Silvestre J-S., Cortivo L. D., P Gaussem P., Emmerich J. Angiogenic potential of BM MSCs derived from patients with critical leg ischemia. Bone Marrow Transplant, v. 47, p. 997-1000, 2012.

Stechschulte L. A., Czernik P. J., Rotter Z. C., Tausif F. N., Corzo C. A., Marciano D. P., et al. PPARG Post-translational modifications regulate bone formation and bone resorption. EBioMedicine, v. 10, p. 174-184, 2016.

Stolzing A., Sellers D., Llewelyn O., Scutt A. Diabetes Induced Changes in Rat Mesenchymal Stem Cells. Cells Tissues Organs, v.191, p. 453-465, 2010.

Taguchi K., Ogawa R., Migita M., Hanawa H., Ito H., Orimo H. The role of bone marrowderived cells in bone fracture repair in a green fluorescent protein chimeric mouse model. Biochem Biophys Res Commun, v. 331, p. 31-36, 2005.

Tanaka K, Yamaguchi T, Kanazawa I, Sugimoto T. Effects of high glucose and advanced glycation end products on the expressions of sclerostin and RANKL as well as apoptosis in osteocyte-like MLOY4-A2 cells. Biochem Biophys Res Commun 461:193-199, 2015.

Tögel F., Weiss K., Yang Y., Hu Z., Zhang P., Westenfelder C. Vasculotropic, paracrine actions of infused mesenchymal stem cells are important to the recovery from acute kidney injury. Am J Physiol Renal Physiol, v. 292, p. 626-635, 2007.

Tolosa M. J., Chuguransky S. R., Sedlinsky C., Schurman L., McCarthy A. D., Molinuevo M. S., Cortizo A. M. Insulin-deficient diabetes-induced bone microarchitecture alterations are associated with a decrease in the osteogenic potential of bone marrow progenitor cells: Preventive effects of metformin. Diabetes Res Clin Pract, v. 101, p. 177-186, 2013.

Vasam G., Joshi S., Jarajapu Y. P. R. Impaired Mobilization of Vascular Reparative Bone Marrow Cells in Streptozotocin-Induced Diabetes but not in Leptin Receptor-Deficient db/db Mice. Sci Rep, v. 6, 2016. 
Vashishth D., Gibson G.J., Khoury J.I., Schaffler M.B., Kimura J., Fyhrie D.P. Influence of nonenzymatic glycation on biomechanical properties of cortical bone. Bone, v. 28, p. 195201, 2001.

Vlassara H., Striker G. E. Advanced Glycation Endproducts in Diabetes and Diabetic Complications. Endocrinol Metab Clin N Am, v. 42, p. 697-719, 2013.

Wang W., Zhang X., Zheng J., Yang J. High glucose stimulates adipogenic and inhibits osteogenic differentiation in MG-63 cells through cAMP/protein kinase A/extracellular signal-regulated kinase pathway. Mol Cell Biochem, v. 338, p. 115-122, 2010.

Weinberg E., Maymon T., Moses O., Weinreb M. Streptozotocin-induced diabetes in rats diminishes the size of the osteoprogenitor pool in bone marrow. Diabetes Res Clin Pract, v. 103, p. 35-41, 2014.

Wu YY, Yu T, Zhang XH, et al. 1,25(OH)2D3 inhibits the deleterious effects induced by high glucose on osteoblasts through undercarboxylated osteocalcin and insulin signaling. J Steroid Biochem Mol Biol, v. 132(1-2), p. 112-119, 2012.

Wu W., Le A. V., Mendez J. J., Chang J., Niklason L. E., Steinbacher. Osteogenic Performance of Donor-Matched Human Adipose and Bone Marrow Mesenchymal Cells Under Dynamic Culture. Tissue Eng Part A, v. 21 (9,10), p. 1621-1632, 2015.

Yamamoto M., Yamaguchi T., Yamauchi M., Sugimoto T. Low serum level of the endogenous secretory receptor for advanced glycation end products (esRAGE) is a risk factor for prevalent vertebral fractures independent of bone mineral density in patients with type 2 diabetes. Diabetes Care, v. 32, p. 2263-8, 2009.

Yan W., Li X. Impact of diabetes and its treatments on skeletal diseases. Front Med, v. 7(1), p. 81-90, 2013.

Yang J., Yan W. Ren C., Li X., Zhang Y., Asahara T., Shen Z. Genome-wide differential gene expression profiling of bone marrow cells in diabetes mellitus type 2 mice. Int $\mathrm{J}$ Clin Exp Med, v. 9 (3), p. 5574-5583, 2016.

Yu L., Tu Q., Han Q., Zhang L., Sui L., Zheng L., et al. Adiponectin Regulates Bone Marrow Mesenchymal Stem Cell Niche through a Unique Signal Transduction Pathway - An Approach for Treating Bone Disease in Diabetes. Stem Cells, v. 33(1), p. 240-252, 2015.

Zhao Y. F., Zeng L., Xia L. G., Zhang S. M., Xu L. Y., Jiang X. Q., Zhang F. Q. Osteogenic potential of bone marrow stromal cells derived from streptozotocin-induced diabetic rats. Int $\mathbf{J}$ Mol Med, v. 31, p. 614-620, 2013.

\footnotetext{
* De acordo com a ABNT NBR 6023.
} 
Anexo A - Arquivo completo dos genes com fold-change $\geq 2.0$ em CD-ROM 